\title{
Dynamics of a subsurface phytoplankton maximum in the Skagerrak*
}

\author{
Peter Koefoed Bjørnsen ${ }^{1}$, Hanne Kaas ${ }^{2}$, Henrik Kaas ${ }^{2}$, Torkel Gissel Nielsen ${ }^{2}$, \\ Michael Olesen ${ }^{1}$, Katherine Richardson ${ }^{3}$
}

\author{
${ }^{1}$ Marine Biological Laboratory, Strandpromenaden 5, DK-3000 Helsinger, Denmark \\ ${ }^{2}$ National Environmental Research Institute, Dept of Marine Ecology and Microbiology, \\ PO Box 358, DK-4000 Roskilde, Denmark \\ ${ }^{3}$ Danish Institute for Fisheries and Sea Research, Charlottenlund Castle, DK-2920 Charlottenlund, Denmark
}

\begin{abstract}
Subsurface maxima in the distribution of autotrophic flagellates and diatoms were found in the nutricline on 3 successive transects across the Skagerrak between Denmark and Norway, during June 1990. The subsurface phytoplankton maximum increased during the 6 d investigation period both in intensity and horizontal extension and followed the nutricline, which descended from ca 15 to ca $25 \mathrm{~m}$ depth, while the pycnocline remained at 5 to $10 \mathrm{~m}$ depth. The descent of the nutricline and the subsurface maximum is interpreted as the utilization of nutrients from the bottom water for new production. This interpretation is supported by a simple dynamic model simulating variations in biomass, irradiance and nutrient concentration with time and depth. About half of the primary production in the water column was associated with the subsurface maximum. Experiments using ${ }^{15} \mathrm{~N}$-nitrate and ${ }^{32} \mathrm{P}$-phosphate confirmed that the subsurface maximum was partly supported by new production, while surface phytoplankton relied mainly on regenerated nutrients. Measurements of heterotrophic activity and vertical carbon flux suggest that the net primary production in the subsurface maximum was roughly evenly allocated to biomass build-up, heterotrophic remineralisation and sedimentation. The heterotrophic community responded to the subsurface phytoplankton maximum with corresponding maxima of bacterioplankton biomass and production and of biomasses of nano-and microzooplankton, whereas copepod biomass remained higher in the surface layer than in the subsurface phytoplankton maximum.
\end{abstract}

\section{INTRODUCTION}

The annual phytoplankton production in temperate marine waters with seasonal stratification is traditionally believed to be dominated by the spring and autumn blooms. During the summer, production and biomass in surface waters are low compared to the bloom periods but still higher than during the winter period (e.g. Cushing 1959, Steele 1974). These recurrent events fit well into the dichotomy of 'new' vs 'regenerated' production (Dugdale \& Goering 1967. Legendre \& Demers 1984, Smetacek \& Pollehne 1986). The spring diatom bloom, triggered by stratification and increased irradiance, rapidly exhausts the pool of nutrients accumulated over winter, collapses and sinks

\footnotetext{
- SKAGEX contribution no. 5
}

to the sea floor (Steele 1974). The heterotrophic response is too slow to provide a significant remineralisation of nutrients, and the spring bloom is consequently largely based on new production. During summer stratification, nutrients remain depleted in the photic zone and the phytoplankton, dominated by small flagellates, are fuelled mainly by regenerated nutrients from a well-established heterotrophic community, and by minor inputs of 'new' nutrients from deep-water entrainment, atmospheric deposition and terrestrial runoff (Rydberg et al, 1990). During early autumn, windinduced mixing of the water column may induce blooms of large dinoflagellates. As in the case of the spring bloom, such autumn blooms are supported by a greater proportion of new production than is the case in surface waters during summer stratification (Lindahl \& Hernroth 1983, Nielsen 1991). 
The Skagerrak and the Kattegat are situated between Denmark, Sweden and Norway and form the mouth of the Baltic to the North Sea (see Fig. 1). A strong pycnocline is maintained throughout the summer by the surface outflow of brackish Baltic water and the bottom counterflow of oceanic water. The pycnocline tilts from a surface front in the North Sea to a bottom front in the Baltic Sea (Pedersen 1990). The spring diatom bloom, the summer flagellate stagnation and the autumn dinoflagellate bloom are all well described for this area. However, attention has recently been drawn to the recurrence of active subsurface phytoplankton maxima associated with the pycnocline.

A spectacular example of this was the subsurface bloom of the nanoflagellate Chrysochromulina polylepis in May-June 1988 that extended over the entire area with an established pycnocline (Barth \& Nielsen 1989, Nielsen et al. 1990, Kaas et al. 1992). However, subsurface maxima of Gyrodinium aureolum have also been observed in the region (Richardson \& Kullenberg 1987, Bjørnsen \& Nielsen 1991). The phytoplankton in the subsurface maxima seem well adapted to low light intensities and apparently benefit from the close contact with the nutrient-rich bottom water. In the southern Kattegat, where the pycnocline is situated at about $15 \mathrm{~m}$ depth, Richardson \& Christoffersen (1991) found that a subsurface phytoplankton maximum was present throughout summer stratification and that it contributed on the order of $30 \%$ of the total annual primary production occurring in this region.

In the central part of the Skagerrak the doming of the pycnocline brings it close to the surface. This means better light conditions in the pycnocline than in the Kattegat but also makes the pycnocline more exposed to wind-induced mixing. Phytoplankton maxima associated with the pycnocline may, therefore, be more transient but also more productive in the Skagerrak than they are in the Kattegat. Distinct subsurface maxima of phytoplankton have been observed in the Skagerrak (Pingree et al. 1982). However, no time series exist to elucidate their dynamics. In this study, we followed the development and fate of a subsurface phytoplankton maximum during 3 successive transects across the Skagerrak. The response of the heterotrophic community was monitored, and nutrient dynamics and sedimentation were assessed to elucidate the relationship between nutrient and light limitations and between new and regenerated production in the subsurface maximum and in the surface phytoplankton. This study was part of the international SKAGEX project organised under the auspices of ICES, during which 15 research vessels obtained synchronous oceanographic data from predetermined transects in the Skagerrak.

\section{MATERIAL AND METHODS}

Sampling stations and program. On 8, 11 and 14 June 1990, samples were taken at 10 stations along an angular section in the Skagerrak between Norway and Denmark (Fig. 1). The sampling programme included continuous profiles of conductivity, temperature and

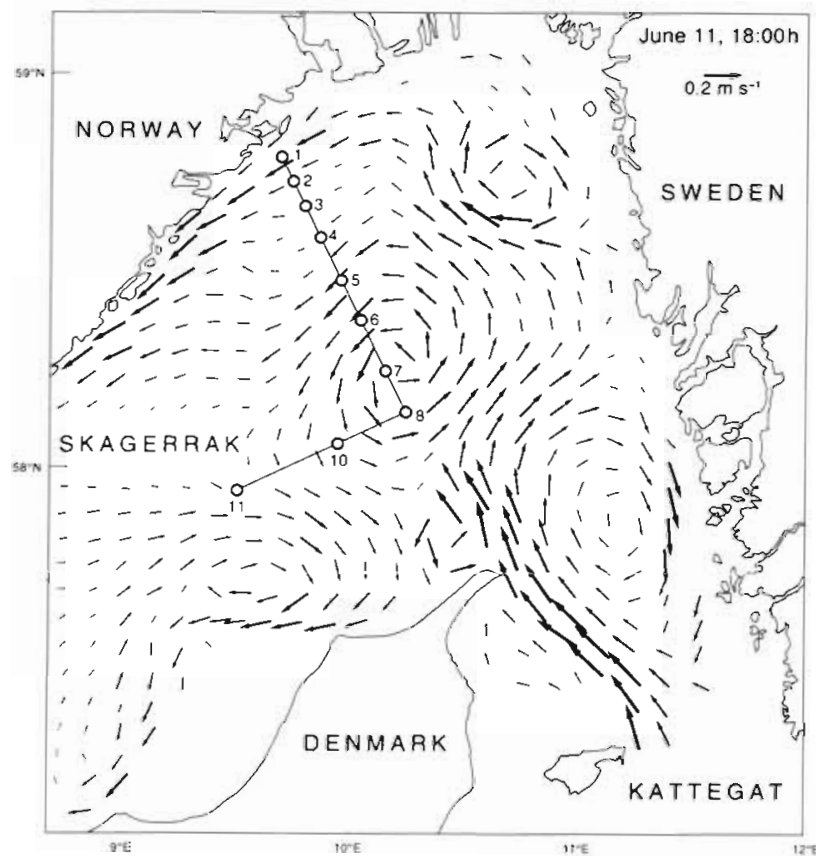

Fig. 1. Study area showing sampling stations and estimated surface currents (B. Dybern pers. comm.) on 11 June 1990

fluorescence. Water samples were taken within the upper $50 \mathrm{~m}$ of the water column with 5 or 301 Niskin bottles. Nutrients (nitrate and phosphate) and chlorophyll a were measured in water samples taken from 4 to 7 different depths including the depth where the maximum fluorescense was observed. Primary production, bacterioplankton biomass and production, and nano- and microzooplankton biomass and composition were measured in a pooled sample from depths of 1,5 and $10 \mathrm{~m}$ representing the mixed surface layer, and in a sample from the depth of the subsurface fluorescence maximum. Nitrate and phosphate uptake and phosphate remineralisation were measured at 3 to 6 depths including the depth of maximum fluorescence on 11 and 14 June at Stns 3 and 5. On 9 and 10 June, chemical and biological parameters were measured at several depths at $\operatorname{Stn} 7$ in the center of the Skagerrak.

Physical measurements. Profiles of salinity (PSU calculated from conductivity) and temperature were obtained with a Neil Brown Mark III CTD. The surface irradiance was recorded throughout the sampling days with a Licor cosine Quantum sensor 4400 to $700 \mathrm{~nm}$, 
data logged as averages of 10 min periods). Light attenuation in the water column was calculated from the Secchi depths and wave heights (Nielsen \& Bresta 1984), and a matrix of in situ photon flux density in the relevant depths was estimated.

Nutrients and particulate $\mathrm{C}, \mathrm{N}$ and $\mathrm{P}$. Concentrations of nitrate and phosphate were measured immediately on board the ship with an ASA automatic nutrient analyser (Carlberg 1972, Olsen \& Lundgren 1984). Particulate organic carbon and nitrogen (POC and PON) were filtered onto precombusted Whatman GF/F filters and analysed with a Perkin Elmer CHNanalyzer $240 \mathrm{C}$. Particulate phosphorus was concentrated on sodium sulphate washed filters and, after washing with $5 \mathrm{ml}$ sodium sulphate, oxidized with potassium peroxydisulphate and measured as phosphate with the ASA autoanalyser.

Phytoplankton biomass. At selected depths (usually 5), chlorophyll a concentrations were measured spectrophotometrically by filtering 2 to 31 of seawater onto GF/F filters and extracting in $96 \%$ ethanol for 6 to 12 h (Jespersen \& Christoffersen 1987). Profiles of in situ fluorescence were measured with a $Q$-Instruments in situ fluorometer The conversion of fluorescence into chlorophyll equivalents was based on an empirical calibration that included parallel measurements of fluorescence and chlorophyll $a$ as described above on 9 samples from the subsurface phytoplankton maximum The conversion factor was estimated as the mean ratio between chlorophyll a concentration and in situ fluorescence. The standard error of the conversion factor was less than $10 \%$.

Primary production. Primary production determinations were made at selected stations on the transects. Incubator capacity did not allow making these determinations at all stations. However, care was taken to select stations in such a manner that all regions of the transects were well represented in the data material. Thus, all stations where primary production measurements were carried out included a sample from the subsurface chlorophyll maximum layer, and approximately every second station additionally included a sample from the mixed surface layer.

Triplicate samples of 25 or $35 \mathrm{ml}$ seawater in acid washed Pyrex bottles were spiked with $2 \mu \mathrm{Ci}$ $\mathrm{NaH}^{14} \mathrm{CO}_{3}$ and placed on a rotating wheel at an irradiance of $388 \mu \mathrm{mol} \mathrm{m} \mathrm{m}^{-2} \mathrm{~s}^{-1}$ (cool white daylight tubes, Philips $35 \mathrm{~W}$, colour 33) and at a temperature corresponding to the bottom of the mixed zone (thermostat regulated, $\pm 1^{\circ} \mathrm{C}$ ). For the fluorescence maximum samples and selected mixed samples, the function of photosynthesis to photon flux density was established ( $P-I$ curve). A seawater sampled $(250 \mathrm{ml})$ was spiked with $40 \mu \mathrm{Ci} \mathrm{NaH}{ }^{14} \mathrm{CO}_{3}$ and distributed into seven $25 \mathrm{ml}$ Pyrex bottles, which were mounted on the rotating wheel. Six bottles were screened by glass neutral-density filters providing irradiances of $0,17,36,52,87$ and $186 \mu \mathrm{mol} \mathrm{m} \mathrm{m}^{-2} \mathrm{~s}^{-1}$. To check the ${ }^{14} \mathrm{C}$ addition, a subsample of $50 \mu \mathrm{l}$ from the incubation media was added to $500 \mu \mathrm{l} \beta$-phenylethylamine and stored for later counting

All incubations were stopped by filtration after $2 \mathrm{~h}$. The samples were filtered onto Whatman $\mathrm{GF} / \mathrm{C}$ filters and dried in glass scintillation vials at $30^{\circ} \mathrm{C}$ for $3 \mathrm{~h}$. The $P-I$ samples were filtered onto $0.45 \mu \mathrm{m}$ cellulose nitrate filters, and exposed to $\mathrm{HCl}$ vapours for $5 \mathrm{~min}$ before transfer to glass scintillation vials. The radioactivity was measured by liquid scintillation counting (LSC). The C-fixation per hour was calculated according to Richardson (1987) and Richardson \& Christoffersen (1991).

In situ daily production rates were estimated from the light matrix, the concentrations of algae given as chlorophyll equivalents and the $P-I$ relationships. In the surface layer, the $P$ vs $I$ curve of the mixed samples was used, and in the subsurface chlorophyll maximum layer, data from the fluorescence maximum sample was used. When no $P-I$ curve was established for the mixed sample, data from a nearby station was used. Daily primary production per $\mathrm{m}^{2}$ was calculated by trapezoid integration.

Bacterioplankton biomass and production. Bacterioplankton cells were counted by epifluorescence microscopy (Hobbie et al. 1977). Water samples of 15 $\mathrm{ml}$ were preserved with $0.5 \mathrm{ml}$ of particle-free neutral formalin $(39 \%)$ and stored refrigerated. Subsamples of $2 \mathrm{ml}$ were mixed with $4 \mathrm{ml}$ of $0.2 \mu \mathrm{m}$ filtered demineralised water, sonicated for $30 \mathrm{~s}$ and filtered onto black $0.2 \mu \mathrm{m}$ polycarbonate filters (25 $\mathrm{mm}$ diameter). The filters were covered with Acridine Orange solution $\left(1 \mathrm{~g} \mathrm{l}^{-1}\right)$ for $2 \mathrm{~min}$ and then sucked dry. At least 200 bacteria were counted at $\times 1250$. A biomass of $20 \mathrm{fg} \mathrm{C}$ cell ${ }^{-1}$ was assumed (Lee \& Fuhrman 1987).

Bacterioplankton net production was estimated from incorporation of ${ }^{3} \mathrm{H}$-thymidine into cold trichloroacetic acid (TCA) precipitate (Fuhrman \& Azam 1980). Duplicate or triplicate samples of $15 \mathrm{ml}$ were incubated with $5 \mathrm{nM}$ of methyl- ${ }^{3} \mathrm{H}$-thymidine $\left(20 \mathrm{Ci} \mathrm{mmol}^{-1}\right.$, New England Nuclear) for $30 \mathrm{~min}$, killed with $0.5 \mathrm{ml}$ of $39 \%$ neutral formalin, and filtered onto $0.45 \mu \mathrm{m}$ cellulose nitrate filters. Filters were rinsed 10 times with $1 \mathrm{ml}$ ice-cold $5 \%$ TCA, transferred to plastic vials, dissolved with $1 \mathrm{ml}$ ethyl acetate for $1 \mathrm{~h}$ and radioassayed by LSC. Prekilled parallel samples were used as blanks. A conversion factor from net thymidine incorporation to net production of 1100 cells fmol $^{-1}$ was used (Riemann et al. 1987, Bjørnsen \& Kuparinen 1991).

Zooplankton biomass. Nanozooplankton (2 to 20 $\mu \mathrm{m})$ were counted and sized by epifluorescence microscopy (Haas 1982). Samples of $7.5 \mathrm{ml}$ were stained 
with proflavine hemisulphate $\left(15 \mu \mathrm{g} \mathrm{ml} \mathrm{m}^{-1}\right)$ for $2 \mathrm{~min}$, fixed by glutaraldehyde $(0.5 \%)$, filtered onto black $0.2 \mu \mathrm{m}$ polycarbonate filters, dried for $15 \mathrm{~s}$, mounted in parafin oil, and stored refrigerated. At least 200 cells were counted at $\times 600$ and classified into (1) autotrophs vs heterotrophs, (2) dinoflagellates vs other flagellates and (3) size classes $(4,8,12$ and $16 \mu \mathrm{m}$ equivalent spherical diameter). A carbon density of $0.12 \mathrm{pg} \mathrm{C}$ $\mu \mathrm{m}^{-3}$ was assumed (Edler 1979).

Microzooplankton (20 to $200 \mu \mathrm{m}$ ) were counted and sized by inverted microscopy (Utermöhl 1958). Samples of 50 or $100 \mathrm{ml}$ fixed by $1 \%$ Lugol's solution were settled overnight and counted at $\times 100$. Identification of ciliates was based on Leegaard (1915), Kahl (1932) and Lynn et al. (1988). Thecate dinoflagellates were identified according to Dodge (1985).

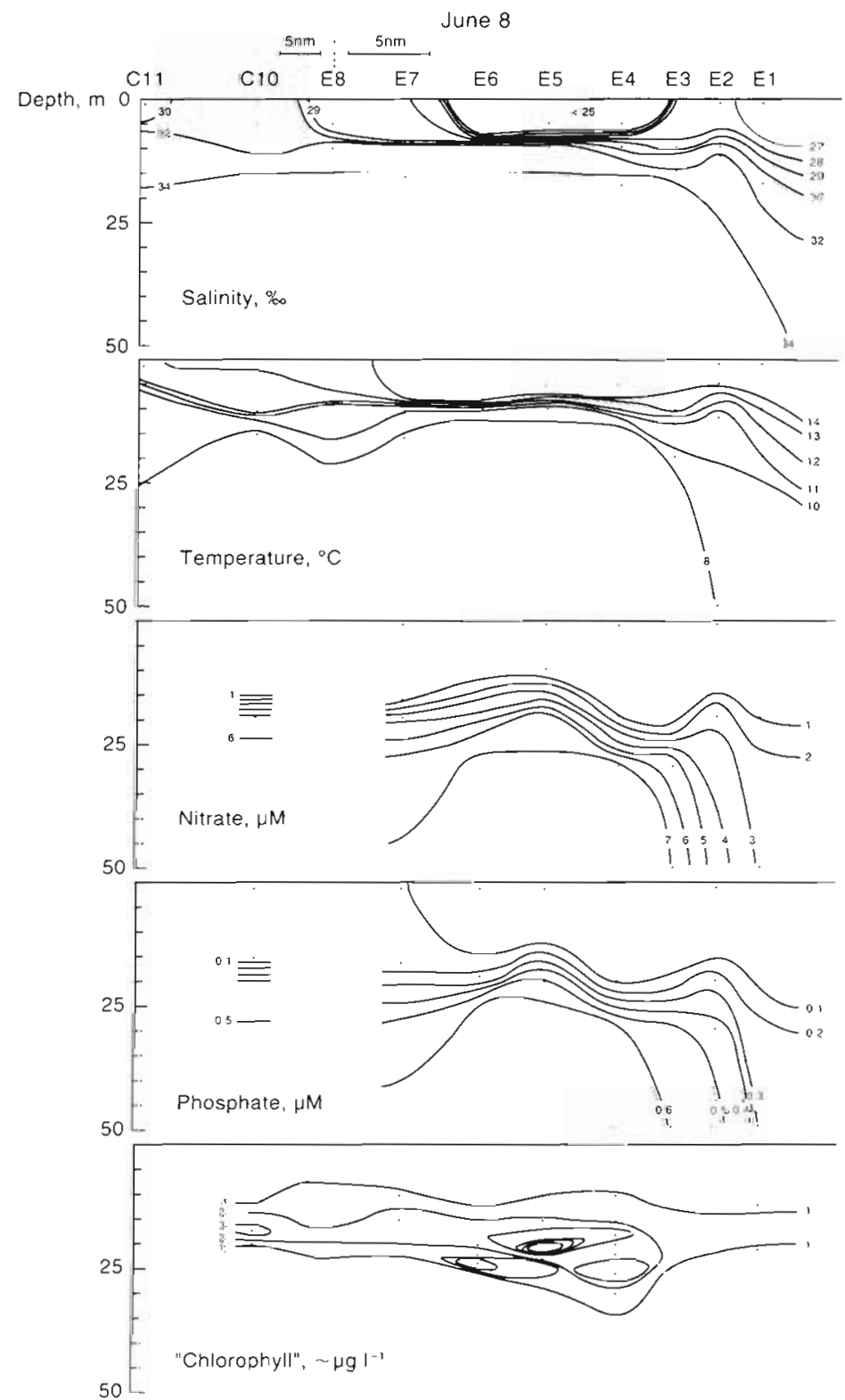

Biovolumes were estimated from measurements of linear dimensions assuming simple geometrical shapes and converted to carbon biomass using conversion factors of $0.073 \mathrm{pg} \mathrm{C} \mathrm{m}^{-3}$ for ciliates (Fenchel \& Finlay

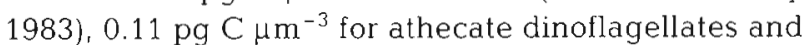

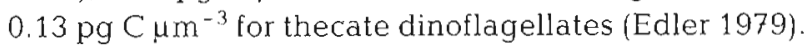

Mesozooplankton (>200 $\mu \mathrm{m})$ were identified, counted and sized in $300 \mathrm{ml}$ samples fixed with $2 \%$ formalin. Biomass was calculated using length-weight regressions cited in Kiørboe \& Nielsen (1990).

Nutrient dynamics. Nutrient dynamics were measured by isotope techniques $\left({ }^{15} \mathrm{~N},{ }^{32} \mathrm{P}\right)$. Incubations took place in $0.5 \mathrm{I}$ polycarbonate bottles in a deck incubator with a constant flow of surface water. The bottles were screened to simulate in situ light conditions.

Nitrate: Uptake of nitrate was measured by adding

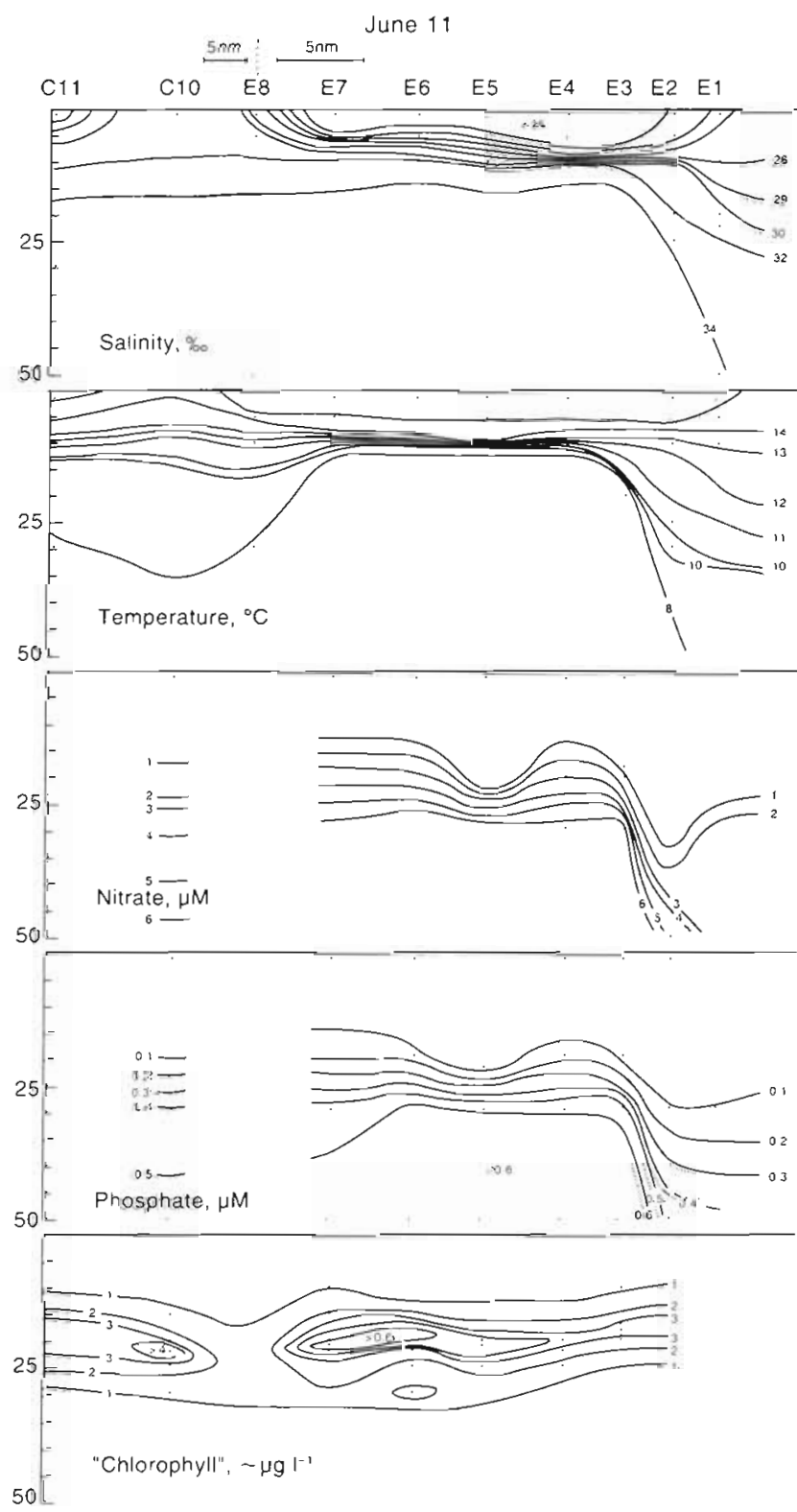


$0.05,0.5$ and $5 \mu \mathrm{M}$ of $\mathrm{Ca}\left({ }^{15} \mathrm{NO}_{3}\right)_{2}$ to water samples of each sampling depth. After 3 to $5.5 \mathrm{~h}$, the experiments were stopped. The samples were treated and the specific $\left(\mathrm{h}^{-1}\right)$ and absolute $\left(\mu \mathrm{gl}^{-1} \mathrm{~d}^{-1}\right)$ uptake rates calculated as described in Kaas et al. (1992). In the surface layer, where the nutrient concentrations were below the detection limit of the autoanalyser $(0.05 \mu \mathrm{M})$, the uptake rates at $0.05 \mu \mathrm{M}$ were calculated.

Phosphate: Uptake and remineralisation of phosphate were measured in $400 \mathrm{ml}$ water samples added tracer amounts of carrier-free ${ }^{32} \mathrm{P}$-orthophosphate. Samples taken after $10 \mathrm{~min}$ (start) and after 2 to $3 \mathrm{~h}$ (end) were filtered onto Whatman GF/F filters. Start and end concentrations of orthophosphate were measured in the filtrates. The ${ }^{32} \mathrm{p}$-activity of filters and filtrate were measured by LSC. Specific phosphate up- take and remineralisation were calculated according to Harrison \& Harris (1986).

Vertical flux of particulate matter. Sedimentation rates were quantified with traps deployed at several depths below the pycnocline at $\operatorname{Stn} 7$. Each trap consisted of a pair of cylindrical sampling tubes with 52 $\mathrm{mm}$ diameter and an aspect ratio (height/diameter) of 6.3. Traps were deployed without preservatives for periods of 24 to $92 \mathrm{~h}$. Aliquots were taken for analyses of chlorophyll a, POC and PON as described above; the remaining fraction of the samples were fixed by $1 \%$ Lugol's solution or by $1 \%$ glutaraldehyde and stored for microscopy. Sedimentation rates were calculated from the difference between concentrations in traps and in ambient water.

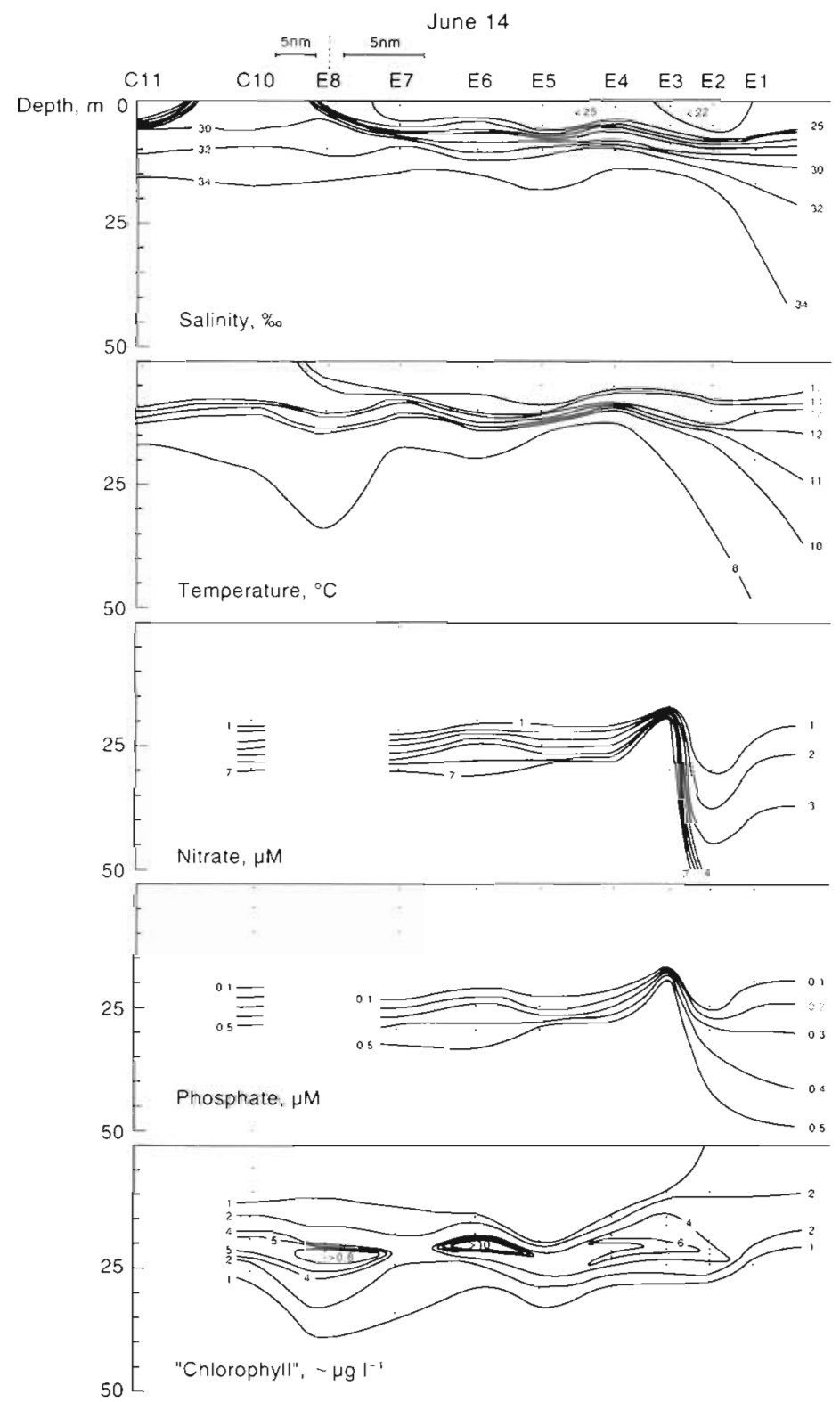

\section{RESULTS}

Most of the sampling stations showed a stratification of the water column into a surface layer of 24 to $29 \%$ salinity and 13 to $17^{\circ} \mathrm{C}$, and a bottom layer of 34 to $35 \%$ salinity and 7 to $8^{\circ} \mathrm{C}$ (Fig. 2). The pycnocline was most distinct in the central part of the transect (Stns 3 to 7) where a pycnocline was found at 5 to $10 \mathrm{~m}$ depth on all 3 transects. Nitrate and phosphate were depleted in the surface water, whereas the bottom water contained ca $8 \mu \mathrm{M}$ nitrate and $0.7 \mu \mathrm{M}$ phosphate. At Stns 3 to 7 , a nutricline was observed at 10 to $20 \mathrm{~m}$ depth on 8 June, at 15 to $25 \mathrm{~m}$ depth on $11 \mathrm{June}$, and at 20 to $30 \mathrm{~m}$ depth on 14 June (Fig. 2). Subsurface chlorophyll maxima were recorded at all stations and were apparently associated with the nutricline rather than with the pycnocline (Fig. 3). The subsurface chlorophyll maximum was most pronounced around the central part of the transect. The horizontal extension of the maximum increased during the study period, as did the maximum chlorophyll concentration (Figs. 2 \& 3). Results obtained during previous cruises along the same transect show that the nutricline had gradually declined since 26 May 1990, when it coincided with the pycnocline (Fig. 3).

From the isopleth diagrams shown in Figs. 2 \& 3, a qualitative image emerges of the prolife-

Fig. 2. Isopleth diagrams of salinity, temperature, nitrate, phosphate, and in situ fluorescence in units of equivalent chlorophyll concentration recorded along the transect (cf. Fig. 1) on 8 June (left), 11 June (center) and 14 June (right). Note different horizontal scales 
ration of a subsurface phytoplankton bloom associated vertically with the nutricline and horizontally with the stratification of the water column. This interpretation has served as a framework for the following attempt to
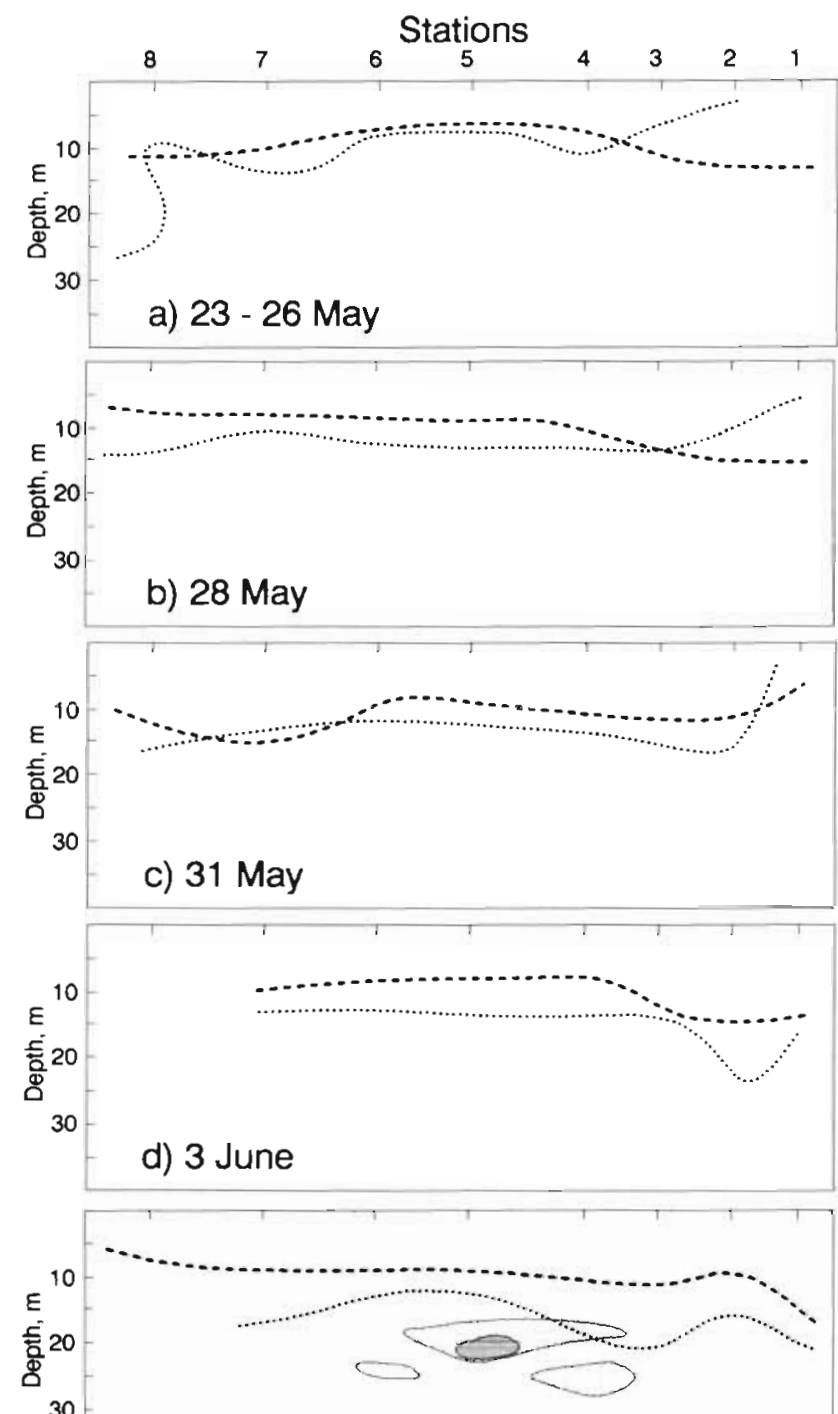

e) 8 June

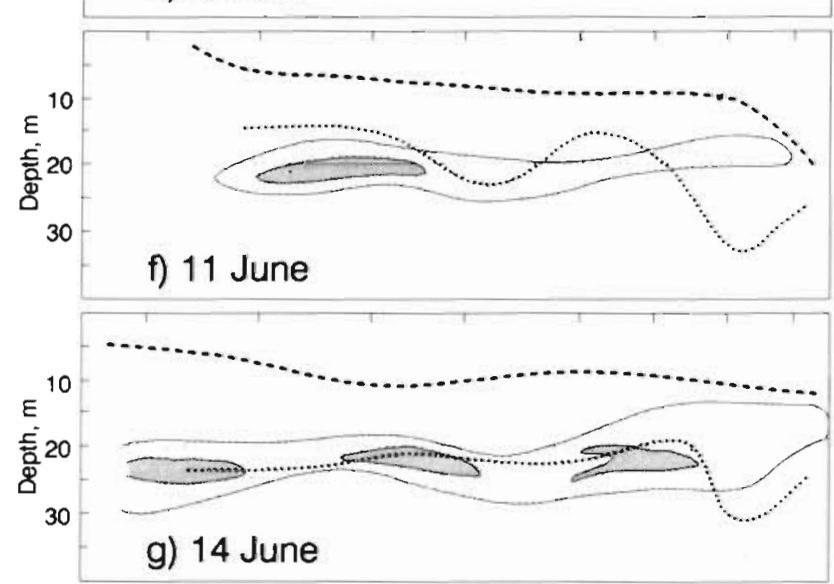

establish a quantitative description of the formation and fate of the phytoplankton bloom in relation to nutrient dynamics, as well as to loss processes including grazing, exudation and sedimentation. We assume that the hydrography of the study area during the period of investigation can be described as a 2-layer system (surface and bottom water that mix in the pycnocline) without interference from the intrusion of a third water mass. We also assume that the transect, when viewed as a whole, represented the study area so well that changes from one transect to the next can be interpreted as changes in time rather than in space. This assumption seems reasonable considering the calm weather and low current speeds during the period (Fig. 1) and the consistency of our data with simultaneous data obtained from other research vessels in the area (Danielssen et al. 1991).

\section{Vertical distribution of plankton}

A detailed assessment of the variation with depth of chemical and biological parameters was carried out at Stn 7 on 9 and 10 June. The pycnocline was found at ca 5 to $10 \mathrm{~m}$ depth, while nitrate and phosphate were depleted in the upper $15 \mathrm{~m}$ of the water column (Fig. 4). Chlorophyll, as estimated from in situ fluorescence, showed a maximum of $4 \mu \mathrm{g} \mathrm{l}^{-1}$ around the nutricline, while concentrations above the pycnocline were 0.3 to $0.6 \mu \mathrm{g} \mathrm{I}^{-1}$. Direct determination of chlorophyll $a$ in discrete water samples by spectrophotometry also showed a subsurface maximum, although only reaching concentrations of 2.0 to $2.2 \mu \mathrm{g} \mathrm{I}^{-1}$. This discrepancy indicates that the water samples were not taken right at the peak depth and it illustrates the difficulties in sampling narrow subsurface maxima by bottle samplers.

The vertical distribution of estimated primary production showed a similar subsurface maximum, although considerable production was estimated in the surface layer where light conditions were most favourable. The irradiance at $30 \mathrm{~m}$ depth was estimated to be 0.5 to $1 \%$ of surface irradiance throughout the study period. The slope of the $P$ vs $I$ curve $(\alpha)$ normalized to chlorophyll a concentration was, on average, significantly higher $(p<0.05)$ for samples from the subsur-

Fig. 3. Position of the pycnocline (30\% salinity isoline, ....) and nutricline ( $1 \mu \mathrm{M} \mathrm{NO}$, isoline,.......$)$ and extension of the subsurface chlorophyll maximum $\left(>3 \mu \mathrm{g} \mathrm{I}^{-1}\right.$ and $>6 \mu \mathrm{gl}^{-1}$ of chlorophyll, light and dark shaded areas respectively) along the E-section in the Skagerrak during SKAGEX 1, May to June 1990. Data were collected from (a) RV 'G. O. Sars', B. Dybern pers. comm.; (b to d) RV 'Arnold Veimer', B. Dybern pers. comm.i and (e to g) RV 'Gunnar Thorson', this study, of. Fig. 2 


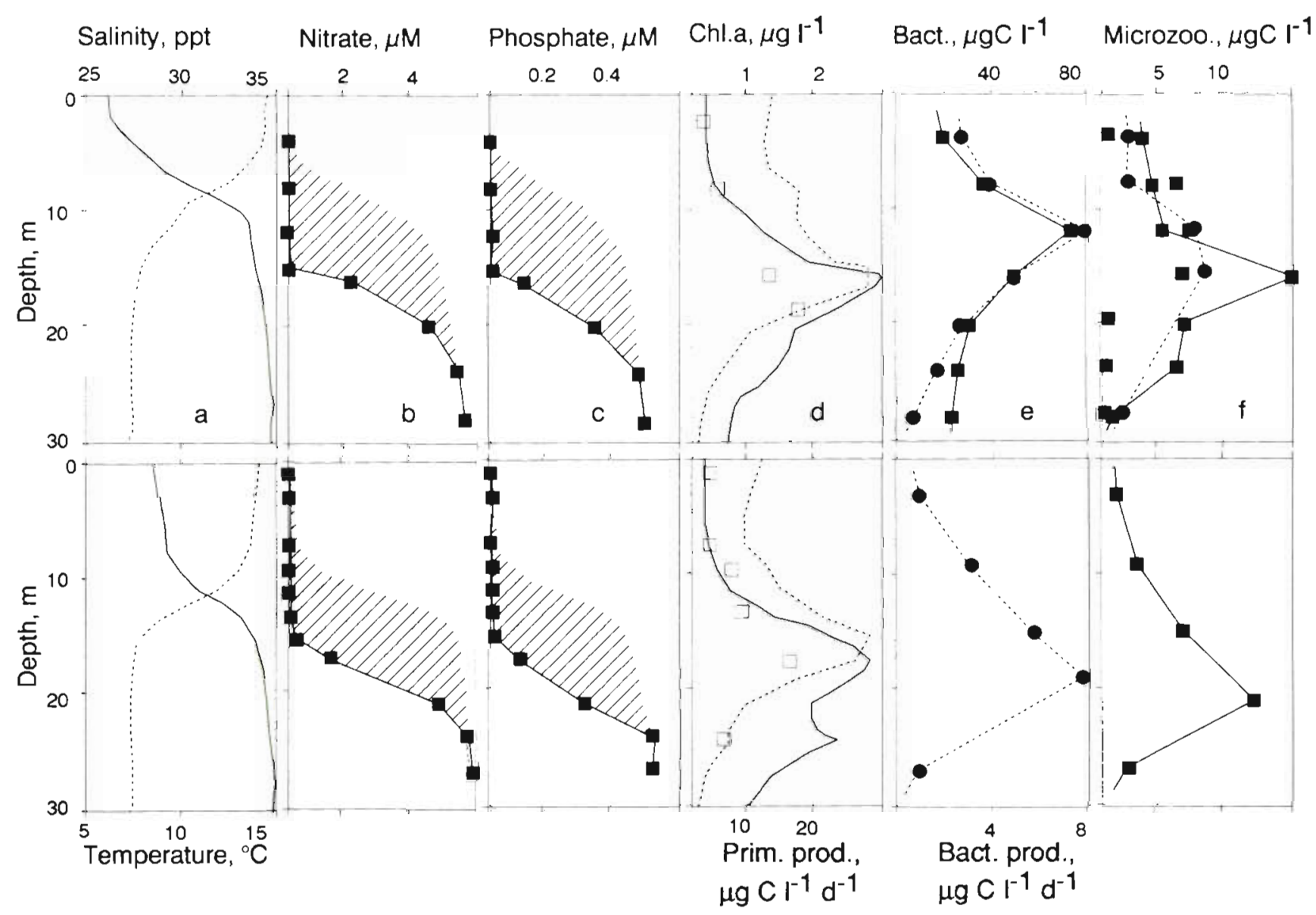

Fig. 4. Vertical profiles of physical, chemical and biological parameters at Stn 7 on 9 June (upper panels) and 10 June (lower panels). (a) Salinity and temperature. (b \& c) Nitrate and phosphate (shaded areas represent deficits, cf. text). (d) Equivalent chlorophyll concentration calculated from in situ fluorescence $(-)$, spectrophotometric determinations of chlorophyll a $(\square)$ and estimated primary production (-.--). (e) Bacterioplankton biomass (- - - ) and production (-.- -.-). (f) Nano- and micro-

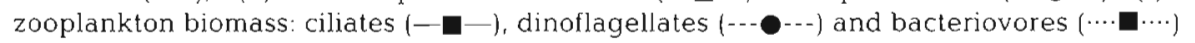

face chlorophyll maximum $\left[0.015 \pm 0.002 \mu \mathrm{g} \mathrm{C} \mathrm{h}{ }^{-1}\right.$ $\left(\mu \mathrm{mol} \mathrm{m} \mathrm{m}^{-2} \mathrm{~s}^{-1}\right)^{-1}(\mu \mathrm{g} \mathrm{chl})^{-1}$, mean $\left.\pm \mathrm{SEM}, \mathrm{n}=15\right]$ than for surface samples $(0.007 \pm 0.001, n=8)$. This difference suggests a photoadaptation to in situ light conditions by both phytoplankton assemblages. No significant difference was, however, observed between the light-saturated rates of photosynthesis normalized to chlorophyll between the surface $\left[1.33 \pm 0.33 \mu \mathrm{g} \mathrm{C} \mathrm{h}^{-1}\right.$ ( $\mu \mathrm{g} \mathrm{chl})^{-1}$ ] and the subsurface assemblages $(1.23 \pm$ 0.20 ). The variability noted for the $P_{\max }$ values may have been due to the fact that production measurements were made at different times during the daylight hours.

Microscopic examination showed that both phytoplankton assemblages consisted of the same diverse mixture of dinoflagellates (dominated by naked forms, e.g. Gymnodinium spp.), cryptophytes, other small flagellates, and diatoms (e.g. Eucambia zodiacus, Rhizosolenia spp. and Nitzschia spp.) (L. Edler pers. comm.).
Bacterioplankton production showed a distinct subsurface peak which, on 10 June, co-occurred with the chlorophyll maximum, while on 9 June, it was displaced a few meters upwards from the chlorophyll maximum (Fig. 4). Bacterial biomass (measured only on 9 June) followed the same vertical distribution as bacterial production, except that the ratio of production-to-biomass decreased with depth, as for phytoplankton. Biomasses of nano- and microzooplankton (including dinoflagellates, other heterotrophic flagellates, and ciliatesj also showed subsurface maxima (Fig. 4). Ciliate biomass reached maximum abundance at the depth of the chlorophyll maximum. Ciliates were dominated by aloricate oligotrichs (e.g. Strombidium oralis, Lohmaniella oviformis, Lohmaniella spiralis, Laboea strobila and Laboea coronata) though tintinnids (e.g. Parafavella denticulata) were also present. On 9 June, heterotrophic dinoflagellates, dominated by naked forms smaller than $20 \mu \mathrm{m}$, reached maximum biomass around the chlorophyll peak, while other het- 


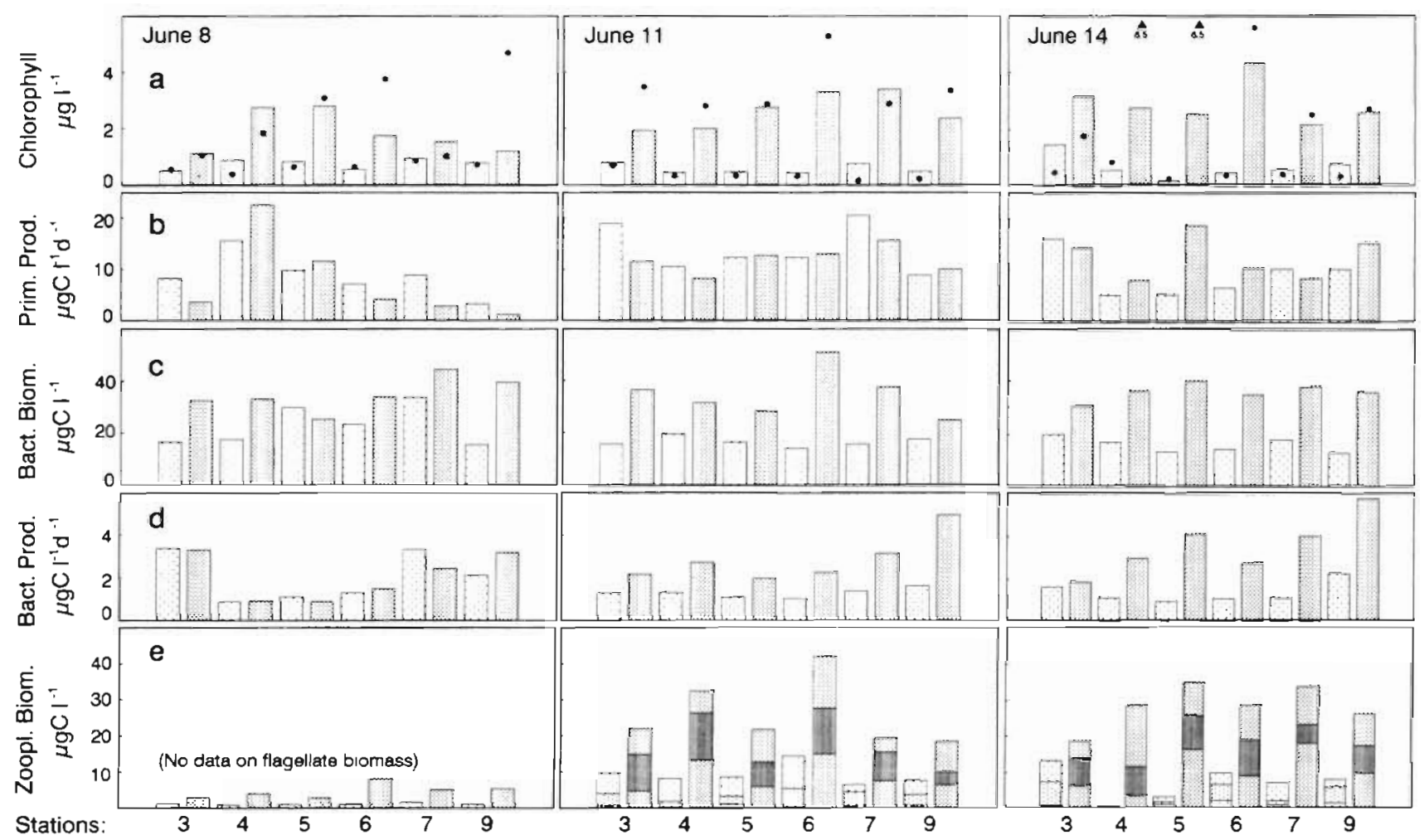

Fig. 5 Biological parameters recorded along the transect ( $\mathrm{cf} F \mathrm{Fg} 1$ ) on 8.11 and 14 June in the surface layer $(0$ to $15 \mathrm{~m}$ depth. light bars) and in the subsurface layer (15 to $30 \mathrm{~m}$ depth, dark bars). (a) Chlorophyll, estumated from in situ fluorescence (bars) or measured directly (•) (b) Estimated primary production (c, d) Bacterioplankton biomass and production. (e) Biomass of ciliates (lower segments of bars). heterotrophıc dinoflagellates (middle segments) and other heterotrophic flagellates (top segments) Flagellate biomass was not quantified on 8 June

erotrophıc nanoflagellates, presumably bacterıvores. showed a maximum closer to the peak in bacterial biomass and production.

During sampling along the transect, heterotrophic biomasses and bacterial production were measured in samples from 2 depths, representing the mixed surface layer (0 to $15 \mathrm{~m}$ depth) and the subsurface chlorophyll maximum (15 to $30 \mathrm{~m}$ depth). These measurements are summarized in Fig 5 and Table 1, together with estimates of average chlorophyll concentration and primary production for the 2 layers. Chlorophyll estimates from the transects confurmed the picture from Fig 2 of low and rather constant concentrations in the surface layer and high and increasing concentrations in the subsurface layer Direct measurements of chlorophyll a demonstrated the same pattern, but were generally about $30 \%$ lower in the surface layer and about $30 \%$ higher in the subsurface layer than parallel estimates from fluorescence. Primary production estimates were approximately equal in the 2 layers. Bacterioplankton biomass and production were higher in the subsurface

Table 1 Average primary and bacterlal production, and heterotrophic biomasses in surface layer $\{0$ to $15 \mathrm{~m}$ depth) and in subsurface layer (15 to $30 \mathrm{~m}$ depth) along the transect (Stns 3 to 7 \& 9. cf Fig 1) HNANO heterotrophic nanoflagellates other than dinoflagellates; HDino; heterotrophic dinoflagellates

\begin{tabular}{|c|c|c|c|c|c|c|}
\hline & \multicolumn{3}{|c|}{ Surface layer } & \multicolumn{3}{|c|}{ Subsurface layer } \\
\hline & $8 \mathrm{Jun}$ & $11 \mathrm{Jun}$ & 14 Jun & 8 Jun & 11 Jun & 14 Jun \\
\hline Measured chl a (ugl') & 06 & 04 & 0.4 & 2.6 & 3.5 & 4.3 \\
\hline Estumated chl a lug l ') & 08 & 0.6 & 0.7 & 1.9 & 2.7 & 3.0 \\
\hline Primary production $\left(\mu \mathrm{g} \mathrm{Cl}^{1} \mathrm{~d}^{1}\right)$ & 88 & 140 & 9.1 & 7.7 & 12.0 & 12.7 \\
\hline Bacterial bromass $\left(\mu \mathrm{g} \mathrm{C}^{-1}\right)$ & 22.7 & 168 & 16.1 & 34.8 & 35.3 & 36.4 \\
\hline Bacterial production $(\mu \mathrm{g} \mathrm{Cl}$ 'd ') & 20 & 13 & 1.4 & 2.0 & 2.9 & 3.6 \\
\hline HNANO biomass ( $\left.\mu \mathrm{g} \mathrm{Cl}^{-1}\right)$ & nd & 54 & 3.6 & nd & 8.1 & 10.0 \\
\hline HDino biomass $\left(\mu \mathrm{g}(:)^{1}\right)$ & nd & 3.4 & 3.5 & nd & 9.1 & 7.9 \\
\hline Ciliate biomass $(\mu g(1)$ & 12 & 08 & 1.4 & 4.7 & 9.2 & 10.9 \\
\hline Copepod bromass $\left(\mu \mathrm{g} \mathrm{Cl}{ }^{1}\right)$ & 58 & 66 & 5.7 & 2.9 & 2.1 & 3.6 \\
\hline
\end{tabular}


than in the surface layer and this difference increased during the study period. Bacterioplankton growth rate was constant at ca $0.08 \mathrm{~d}^{-1}$ in both layers.

Flagellate biomass was not determined on 8 June. However, measurements on 11 and 14 June showed higher biomasses in the subsurface than in the surface layer for heterotrophic dinoflagellates as well as for other heterotrophic flagellates (Fig. 5, Table 1). Ciliate biomass was low and constant in the surface layer while higher and increasing in the subsurface layer. Most of the heterotrophic community, thus, responded positively to the higher phytoplankton biomass in the subsurface layer. Copepod biomass, however, exhibited the exception to this pattern and was highest in the surface layer (Table 1). Copepods were dominated by Calanus finmarchicus, Paracalanus parvus, Pseudocalanus spp. and Oithona sp.

\section{Nutrient dynamics and sedimentation}

Throughout the study, a nutricline was found between 5 and $10 \mathrm{~m}$ below the pycnocline (Figs. 2 to 4 ) indicating that the nutrients in the upper part of the normally nutrient rich bottom water had been depleted. The vertical profiles of nitrate and phosphate concentrations that would result from simple mixing of surface and bottom water were calculated for each station as: $n_{\mathrm{x}}=n_{1}\left(\mathrm{~S}_{\mathrm{x}}-\mathrm{S}_{0}\right) /\left(\mathrm{S}_{1}-\mathrm{S}_{0}\right)$, where $n=$ nutrient concentration; $S=$ salinity; and 0,1 and $x=$ surface water, bottom water and intermediate depths, respec-

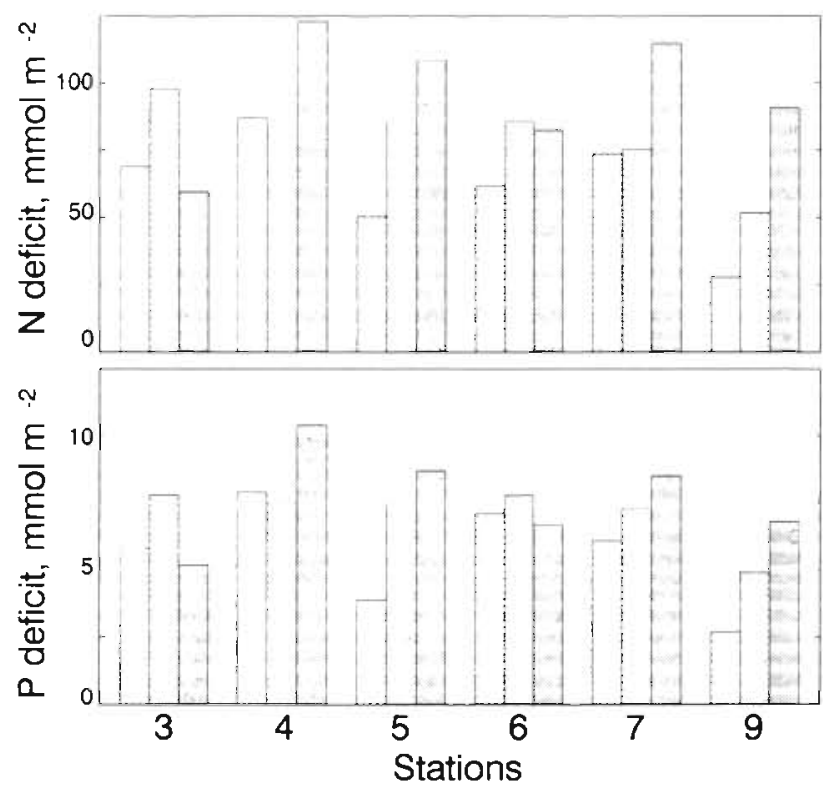

Fig. 6. Depth-integrated nutrient deficits of nitrate and phosphate (cf. text) at Stns 3 to 7 and 9. Each cluster gives estimates from 8,11 and 14 June (left, center and right bar, respertively)
Table 2. Mean integrated nutrient deficits $\left(\mathrm{mmol} \mathrm{m}^{-2}\right)$ and chlorophyll ( $\mathrm{mg} \mathrm{m}^{-2}$ ) values along the transect (Stns 3 to 7 \& 91

\begin{tabular}{|ccccccc|}
\hline & 8 Jun & & 11 Jun & & 14 Jun \\
\hline $\begin{array}{l}\text { Nitrate deficit } \\
\text { Increase }\end{array}$ & 61.7 & & 79.5 & & 96.6 \\
$\begin{array}{l}\text { Phosphate deficit } \\
\text { Increase }\end{array}$ & 5.6 & 17.8 & & 17.1 & \\
$\begin{array}{l}\text { Chlorophyll } \\
\text { Increase }\end{array}$ & 38.0 & & 4.1 & & 7.7 \\
\hline
\end{tabular}

tively. The differences between these 'potential' nutrient concentrations and those actually measured (illustrated as the hatched areas on Fig. 4) were interpreted as 'deficits' and were supposed to represent an accumulated consumption by phytoplankton for 'new' production (sensu Dugdale \& Goering 1967).

Depth-integrated nutrient deficits ranged from 30 to $120 \mathrm{mmol} \mathrm{N} \mathrm{m}^{-2}$ and from 3 to $10 \mathrm{mmol} \mathrm{P} \mathrm{m}^{-2}$ (Fig. 6). Both nitrate and phosphate deficits seemed to increase during the study period, with the exception of Stns 3 and 6 (Fig. 6). On average, for Stns 3 to 7 and 9 , the nitrate deficit increased by $35 \mathrm{mmol} \mathrm{m}^{-2}$ during the period, corresponding to $5.8 \mathrm{mmol} \mathrm{m}^{-2} \mathrm{~d}^{-1}$, while the phosphate deficit increased by $2.1 \mathrm{mmol} \mathrm{m}^{-2}$ or 0.35 mmol m-2 $\mathrm{d}^{-1}$ (Table 2). High ammonia concentrations were found close to the Norwegian coast (at Stns $1 \& 2$ ) while concentrations further offshore (Stns 3 to 7) were mostly below $0.1 \mu \mathrm{M}$ and consistently below $0.25 \mu \mathrm{M}$ (data not shown).

Nutrient dynamics were studied at selected stations through direct measurements of nitrate uptake and uptake and remineralisation of phosphate using ${ }^{15} \mathrm{~N}$ and ${ }^{32} \mathrm{P}$. Specific nitrate uptake ranged from 0.00016 to $0.0044 \mathrm{~h}^{-1}$, with $V_{\max }-v a l u e s$ of 0.00051 to $0.0044 \mathrm{~h}^{-1}$. The uptake (specific as well as absolute) was highest in the lower part of the fluorescence maximum layer, following the increasing nitrate concentrations.

Nitrate uptake is influenced by both nitrate concentration and irradiance. With the limited data set available, it was not possible to construct a model taking both parameters into account simultaneously. Instead, data on ${ }^{15} \mathrm{~N}$-nitrate uptake were treated differently for surface and subsurface samples. For surface samples, where ambient nitrate concentrations were always below the $0.05 \mu \mathrm{M}$ detection limit of the analysis, specific nitrate uptake showed a hyperbolic relationship to light intensity with inhibition of the uptake at irradiances above ca $650 \mu \mathrm{mol} \mathrm{m} \mathrm{m}^{-2} \mathrm{~s}^{-1}$ (Fig. 7). For the subsurface chlorophyll layer, we assumed that nitrate uptake was affected by nitrate concentration rather than by light. Specific nitrate uptake was related to ambient 


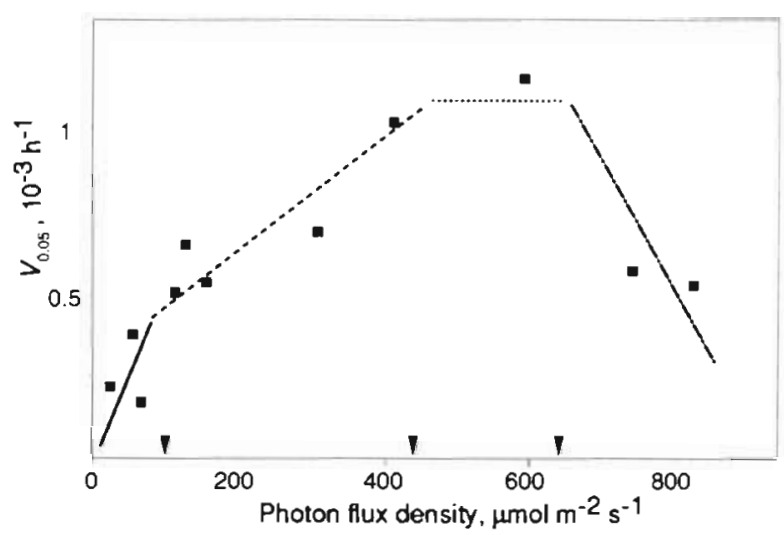

Fig. 7 Specific nitrate uptake plotted against irradiance for surface samples

nitrate concentration and fitted by a linear relationship for nitrate concentrations below $6.3 \mu \mathrm{M}[V=0.50 \times$ $10^{-3}$ (ambient $\mathrm{NO}_{3}{ }^{-}$conc.) $+0.46 \times 10^{-3}, \mathrm{n}=8, \mathrm{r}^{2}=$ $0.69)$ and a constant $\left(V=3.6 \times 10^{-3} \mathrm{~h}^{-1}, \mathrm{n}=4, \mathrm{SE}=\right.$ $0.5 \times 10^{-3}$ ) for higher concentrations (data not shown).

Daily uptake of nitrate was calculated for the surface and subsurface layers from the light matrix and measured PON and $\mathrm{NO}_{3}{ }^{-}$concentrations at several depths and the uptake per $\mathrm{m}^{2}$ was calculated by trapezoid integration. This calculation yields overestimates of nitrate uptake in surface water, where a nitrate concentration of $0.05 \mu \mathrm{M}$ was assumed. Depth integrated nitrate uptake averaged less than 0.45 (range 0.3 to $0.8, \mathrm{n}=6) \mathrm{mmol} \mathrm{m}^{-2} \mathrm{~d}^{-1}$ in the surface layer (0 to $15 \mathrm{~m}$ ) and averaged 1.3 (range 0.4 to $4.6, \mathrm{n}=6$ ) $\mathrm{mmol} \mathrm{m}^{-2} \mathrm{~d}^{-1}$ for the subsurface layer.

Assuming a molar $\mathrm{C}: \mathrm{N}$ uptake ratio of 6.6 , the nitrogen demand can be estimated from the primary production. Nitrate uptake could meet 4 to $11 \%$ of this demand in the upper fluorescence peak (Table 3 , $f$-values), where nitrate concentrations were low $(<1.5 \mu \mathrm{M})$. At higher concentrations (lower maximum layer, except Stn 5, 14 June), the nitrate uptake could account for 23 to $489 \%$ of the calculated demand.

Specific phosphate assimilation rates ranged from 0.01 to $0.32 \mathrm{~h}^{-1}$, while specific remineralisation rates (i.e. remineralisation rate divided by particulate organic phosphorous, POP) ranged from 0.01 to $0.51 \mathrm{~h}^{-1}$. When specific remineralisation rates were plotted

Table 3. Daily primary production and nitrate and phosphate uptake in the surface and the subsurtace chlorophyll maximum layer. $f=(100 \times$ nitrate- $N$ uptake $) /$ total nitrogen demand (calculated from primary production, $C: N$ weight ratio $=5.7)$. Values in parentheses indicate that $f$ is overestimated because the nitrate uptake is calculated for $0.05 \mu \mathrm{M}$ while the nitrate concentrations were $<0.05 \mu \mathrm{M}$

\begin{tabular}{|c|c|c|c|c|c|}
\hline Location & $\begin{array}{l}\text { Depth } \\
(\mathrm{m})\end{array}$ & $\begin{array}{c}\text { Primary } \\
\text { production } \\
\left(\mu \mathrm{gCl}^{-1} \mathrm{~d}^{-1}\right)\end{array}$ & $\begin{array}{c}\text { Nitrate } \\
\text { uptake } \\
\left(\mu g N l^{-1} d^{-1}\right)\end{array}$ & $\begin{array}{c}\text { Phosphate } \\
\text { uptake } \\
\left(\mu g \mathrm{P}^{-1} \mathrm{~d}^{-1}\right)\end{array}$ & $\begin{array}{c}f \\
(\%)\end{array}$ \\
\hline \multicolumn{6}{|l|}{9 Jun, Stn 7} \\
\hline Surface & 3 & 5.7 & 0.468 & 0.79 & $(47)$ \\
\hline \multirow[t]{2}{*}{ Subsurface } & 15 & 32.9 & 0.265 & 4.46 & 5 \\
\hline & 17.5 & 19.4 & 0.862 & 2.42 & 25 \\
\hline \multicolumn{6}{|l|}{$10 \mathrm{Jun}, \operatorname{Stn} 7$} \\
\hline Surface & 2.5 & 8.4 & 0.43 & 0.99 & (29) \\
\hline \multirow[t]{2}{*}{ Subsurface } & 18 & 29 & 0.55 & 0.59 & 11 \\
\hline & 25 & 6.4 & 0.86 & 0.86 & 76 \\
\hline \multicolumn{6}{|l|}{ 11. June, $\operatorname{Stn} 3$} \\
\hline Surface & 5 & 15.5 & 0.47 & 3.04 & $(17)$ \\
\hline \multirow[t]{2}{*}{ Subsurface } & 17 & 23.8 & 0.21 & 1.84 & 5 \\
\hline & 20 & 14.2 & 1.29 & 0.74 & 52 \\
\hline \multicolumn{6}{|l|}{11 Jun, Stn 5} \\
\hline Surface & 5 & 8.4 & 0.43 & 3.90 & (29) \\
\hline \multirow[t]{2}{*}{ Subsurface } & 20 & 20.0 & 0.12 & 2.75 & 3 \\
\hline & 22 & 20.9 & 0.86 & 6.74 & 23 \\
\hline \multicolumn{6}{|l|}{14 Jun, $\operatorname{Stn} 3$} \\
\hline Surface & 5 & 6.7 & 0.32 & 0.62 & $(27)$ \\
\hline Subsurface & 17 & 27.7 & 3.36 & 0.53 & 69 \\
\hline \multicolumn{6}{|l|}{14 Jun, Stn 5} \\
\hline Surface & 5 & 8.9 & 0.34 & 0.50 & (22) \\
\hline \multirow[t]{2}{*}{ Subsurface } & 25 & 38.1 & 8.99 & 0.65 & 1.34 \\
\hline & 30 & 7.8 & 6.80 & 0.11 & 489 \\
\hline
\end{tabular}




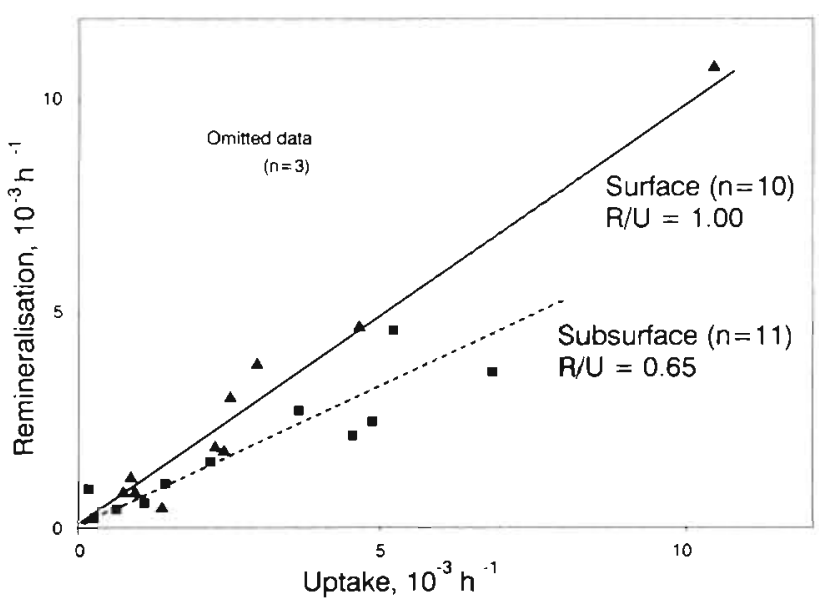

Fig. 8. Remineralisation rates plotted against uptake rates of phosphate for surface ( $\mathbf{\Delta}$ ) and subsurface samples (a). R/U is the mean ratio between remineralisation and uptake

against specific uptake rates, the data separated into surface samples with ratios close to 1.00 , and subsurface samples with ratios close to 0.65 (Fig. 8) Three data points with ratios above 2 were excluded. Specific phosphate assimilation rates in surface samples increased with irradiance up to $400 \mu \mathrm{mol} \mathrm{m} \mathrm{m}^{-2} \mathrm{~s}^{-1}$ and were inhibited at irradiances above approx. $600 \mu \mathrm{mol}$
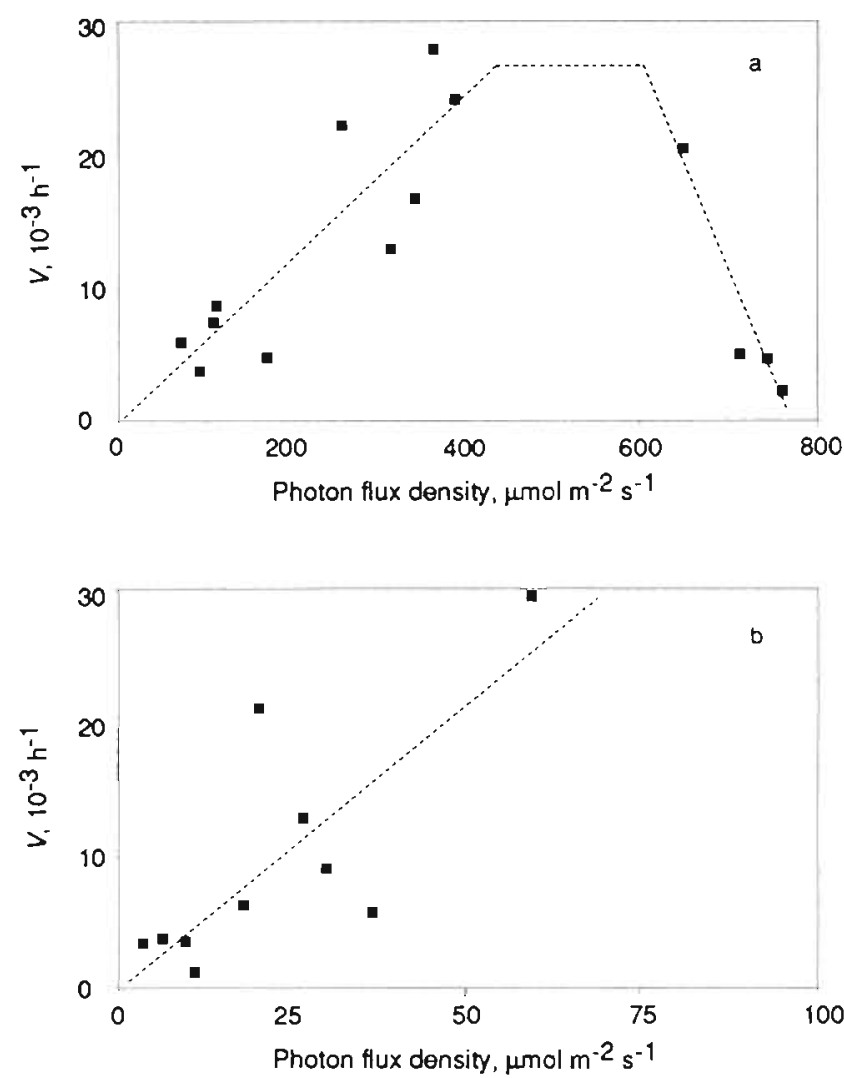

Fig. 9. Specific phosphate uptake plotted against irradiance for (a) surface and (b) subsurface samples $\mathrm{m}^{-2} \mathrm{~s}^{-1}$ (Fig. 9a). In subsurface samples, the specific phosphate assimilation rate increased with irradiances up to $60 \mu \mathrm{mol} \mathrm{m} \mathrm{m}^{-2} \mathrm{~s}^{-1}$ and reached much higher rates than surface samples at similar irradiances (Fig. 9b). Diel rates of phosphate uptake (Table 3) were calculated for surface and subsurface layers from measured insolation using the relationships shown in Fig. 9. Depth integrated phosphate uptake ranged from 0.3 to $1.0 \mathrm{mmol} \mathrm{m} \mathrm{m}^{-2} \mathrm{~d}^{-1}$ for the surface layer and from 0.1 to $1.2 \mathrm{mmol} \mathrm{m}^{-2} \mathrm{~d}^{-1}$ for the subsurface layer. The ratio between primary production and phosphate uptake averaged $21 \mathrm{~g} \mathrm{C}: \mathrm{g} P(\mathrm{n}=16, \mathrm{SE}=5.7)$ and was significantly lower than the expected ratio of 41 (Redfield 1958)

On 10 June, the depth variation of nitrate uptake at Stn 7 seemed to follow the nitrate concentration rather than chlorophyll concentration or irradiance (Fig. 8), while the depth variation of phosphate uptake showed a peak at $18 \mathrm{~m}$ depth corresponding to the depth of the

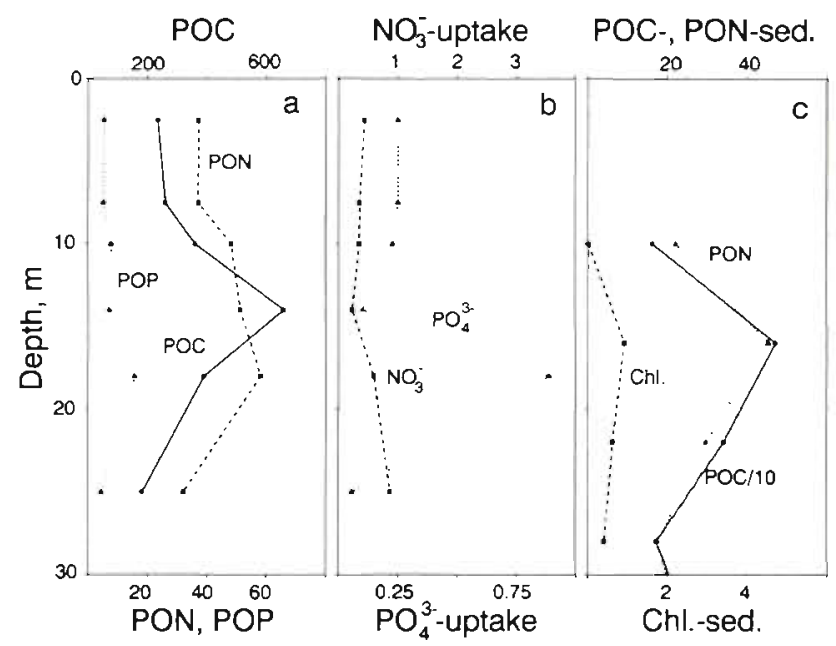

Fig. 10. Nutrient and particle dynamics at $\operatorname{Stn} 7$ on 10 June. (a) POC, PON and POP concentrations (all in $\mu \mathrm{g} \mathrm{l}^{-1}$ ). (b) Nitrate and phosphate uptake rates from isotope experiments (in $\mu \mathrm{g}$ $\mathrm{l}^{-1} \mathrm{~d}^{-1}$ ). (c) Sedimentation flux rates of chlorophyll, POC and PON in $\mathrm{mg} \mathrm{m}^{-2} \mathrm{~d}^{-1}$

fluorescence peak. Measurements of vertical flux by sediment traps deployed at different depths showed a maximum flux at $16 \mathrm{~m}$ depth (Fig. 10), while vertical fluxes measured between 10 and 14 June showed no significant differences between depths (Table 4). The vertical flux of organic carbon averaged $283 \mathrm{mg} \mathrm{C} \mathrm{m}^{-2}$ $\mathrm{d}^{-1}$ on 9 and 10 June and $105 \mathrm{mg} \mathrm{C} \mathrm{m}^{-2} \mathrm{~d}^{-1}$ on 10 to 14 June (Table 4). The weight-based $\mathrm{C}: \mathrm{N}$ ratio of the sedimenting material averaged 10 compared to a $C: N$ ratio of the particulate organic material of 6 , indicating that the settling organic material had undergone some decomposition already. This was further supported by the high $\mathrm{C}$ : chlorophyll ratio in the sedimenting mate- 
Table 4. Vertical fluxes of carbon, nitrogen and chlorophyll a measured by sedimentation traps at Str 7

\begin{tabular}{|ccccc|}
\hline Period & $\begin{array}{c}\text { Depth } \\
(\mathrm{m})\end{array}$ & $\begin{array}{c}\mathrm{C} \\
\left(\mathrm{mg} \mathrm{m}^{-2} \mathrm{~d}^{-1}\right)\end{array}$ & $\begin{array}{c}\mathrm{N} \\
\left(\mathrm{mg} \mathrm{m}^{-2} \mathrm{~d}^{-1}\right)\end{array}$ & $\begin{array}{c}\mathrm{Chl} \mathrm{a} \\
\left(\mathrm{mg} \mathrm{m}^{-2} \mathrm{~d}^{-1}\right)\end{array}$ \\
\hline 9 \& 10 June & 10 & 305 & 30 & 0.0 \\
& 16 & 452 & 44 & 0.9 \\
& 22 & 243 & 29 & 0.6 \\
& 28 & 175 & 17 & 0.4 \\
10 \& 14 June & 34 & 240 & 27 & 0.0 \\
& 10 & 145 & 10 & 0.5 \\
& 22 & 89 & 6 & 0.3 \\
& 34 & 89 & 9 & 0.1 \\
& 46 & 98 & 11 & 0.0 \\
\hline
\end{tabular}

half-saturation concentration $\left(K_{m}\right)$ of $72 \mu \mathrm{g}$ $\mathrm{C}^{-1}$ corresponding to $1 \mu \mathrm{M}$ of nitrate. Specific photosynthesis rate $(P)$ is calculated as specific gross production rate minus specific respiration rate $(R)$. Irradiance decreases with depth due to absorption by water $\left(A_{\mathrm{w}}\right)$ and biomass $\left(B \times A_{B}\right)$. Nutrients are consumed by phytoplankton production and dispersed by turbulent mixing. Biomass is increased by growth $(B \times P)$ minus loss $(B \times M$, where $M=$ loss rate), dispersed by turbulent mixing, and transported down wards by sinking (Table 5).

It is important to note the difference rial (Table 4). Similar high C.N and C:chlorophyll ratios were estimated from sediment traps deployed for only a few hours (data not shown).

\section{DISCUSSION}

Our observations are in accordance with those reported from previous investigations on subsurface phytoplankton maxima in the Skagerrak. Rosenberg et al. (1990) found subsurface phytoplankton maxima around the pycno/nutricline during May 1987 at several stations in the Skagerrak. Pingree et al. (1982) found a narrow maximum of about $20 \mu \mathrm{g}$ chlorophyll $1^{-1}$ in the nutricline ca $10 \mathrm{~m}$ below the pycnocline at a central station in the Skagerrak in August 1981 During a cruise in the North Sea in May 1990, Nielsen et al. (1993) found subsurface maxima of phytoplankton biomass and production and heterotrophic biomass in the thermocline. In the present study carried out in June 1990, the subsurface chlorophyll maximum was observed well below the pycnocline and associated with a nutricline for nitrate and phosphate. The nutricline moved downwards during the study period of $1 \mathrm{wk}$, and this was interpreted as the consumption of nutrients by a slowly descending phytoplankton assemblage.

To test this interpretation, a simple 1-dimensional model was constructed with 3 state variables of time and depth: phytoplankton biomass $(B)$, nutrient concentration $(N)$ and irradiance $(I)$. For the sake of simplicity, nutrient concentration was quantified in terms of equivalent $\mu \mathrm{g} \mathrm{Cl}^{-1}$, as converted by Redfield's ratio (Redfield 1958).

The model attempts a synthesis of nutrient and light limitation of photosynthesis around the nutricline, selfshading, turbulent mixing, sinking, and sedimentation loss. Specific photosynthesis rate is assumed to be proportional to irradiance and to follow Michaelis-Menten kinetics with respect to nutrient concentration with a between loss, respiration and sinking. In this model, the loss component $M$ is confined strictly to those processes that lead to an export of nutrients from the system, such as the rapid sedimentation of particle aggregates and zooplankton fecal pellets. The sinking rate $S$, on the other hand, deals with the much slower sinking of single phytoplankton cells that remain photosynthetically active. Grazing and excretion of dissolved organic matter are not explicitly included in the model, but these processes will ultimately lead either to biomass build-up, respiration/remineralisation, or loss/export, and hence they can be regarded as implicitly incorporated in the components $P, R$ and $M$.

An exponential formulation of the model was implemented in an ordinary spreadsheet software with 20 version of the model may be obtained on diskette by request to the first author.) A run of the model, with parameter settings as given in Table 5 , shows the buildup of a biomass peak in the nutricline followed by the concurrent descent of biomass peak and nutricline by about $0.4 \mathrm{~m} \mathrm{~d}^{-1}$ (Fig. 11). When run with different parameter settings and start conditions, the model proved to be robust with respect to the qualitative pattern of the output as shown in Fig 11. Quantitatively, nutrient consumption for 'new production' depends strongly on $\alpha$ (specific photosynthetic efficiency) and $I_{0}$ (irradiance), while biomass build-up depends more on the loss rate $M$. The sinking component $S$ increases nutrient consumption rate, but is not necessary to simulate the descent of the biomass peak. At sinking rates above ca $5 \mathrm{~cm} \mathrm{~h}^{-1}$. phytoplankton will sink too rapidly to exhaust nutrients. Turbulence, on the other hand, may exert a strong control on the development of subsurface maxima. At turbulent diffusivities above $10^{-5}$ $\mathrm{m}^{-2} \mathrm{~s}^{-1}$, corresponding to the lower end of the range given by Pond \& Pickard (1989) for marine environments, the model fails to produce a biomass peak with the other constants set as given in Table 5 .

The apparent descent rates in phosphate and nitrate layers each $0.5 \mathrm{~m}$ in depth and with 28 time steps. (This 
Table 5. A multilayer phytoplankton-nutrient-light model. Independent variables are time ( $t$, in hours) and depth ( $l$, in $\mathrm{cm})$

\begin{tabular}{|c|c|c|c|c|}
\hline Constants & Symbol & Unit & Value & Source \\
\hline Turbulent diffusivity & $D$ & $\mathrm{~cm}^{2} \mathrm{~h}^{-1}$ & 36 & Pond \& Pickard (1989) \\
\hline Absorbance by water & $A_{\mathrm{w}}$ & $\mathrm{cm}^{-1}$ & $2 \times 10^{-3}$ & Weast (1975) \\
\hline Absorbance by biomass & $A_{\mathrm{B}}$ & $\mathrm{cm}^{-1}\left(\mu \mathrm{gCl}^{-1}\right)^{-1}$ & $6 \times 10^{\text {ba }}$ & Taylor et al. (1986) \\
\hline Photosynthetic efficiency & $\alpha$ & $\mathrm{h}^{-1}\left(\mathrm{umolm} \mathrm{m}^{-2} \mathrm{~s}^{-1}\right)^{-1}$ & $103 \ldots b$ & Table 2 \\
\hline Nutrient half saturation & $K_{m}$ & $\mu \mathrm{gCl}^{-1}$ & 72 & Eppley et al. (1969) \\
\hline Loss rate & $M$ & $h^{-1}$ & $5 \times 10^{-3 x}$ & Tables $3 \& 6$ \\
\hline Respiration rate & $R$ & $h^{-1}$ & $5 \times 10^{-3}$ & Harris (1978) \\
\hline Sinking rate & $S$ & $\mathrm{~cm} \mathrm{~h}^{-1}$ & 0.5 & Bienfang et al. (1982) \\
\hline Irradiance at top layer & $I_{0}$ & $\mu \mathrm{mol} \mathrm{m} \mathrm{m}^{-2} \mathrm{~s}^{-1}$ & $75^{\circ}$ & $10 \%$ of surface irradiance \\
\hline Dependent variables & Symbol & Unit & \multicolumn{2}{|c|}{ Equation } \\
\hline Biomass & $B$ & $\mu \mathrm{gCl}^{-1}$ & \multicolumn{2}{|c|}{$\frac{\delta B}{\delta t}=B(P-M)+D \frac{\delta^{2} B}{\delta I^{2}}-S \frac{\delta B}{\delta l}$} \\
\hline Nutrient concentration & $N$ & $\mu \mathrm{gCl}^{-1}$ & \multicolumn{2}{|c|}{$\frac{\delta N}{\delta t}=-B \cdot P+D \frac{\delta^{2} N}{\delta l^{2}}$} \\
\hline Irradiance & $I$ & $\mu E m^{-2} s^{-1}$ & \multicolumn{2}{|c|}{$\frac{\delta I}{\delta I}=-I\left(A_{w}+B A_{B}\right)$} \\
\hline $\begin{array}{l}\text { Production } \\
\text { a Assuming } \mathrm{C}: \mathrm{chl}=30 \\
{ }^{\mathrm{t}} \text { Assuming a factor of } 2 \text { ur } \\
\text { "Diel mean }\end{array}$ & $\begin{array}{c}P \\
\text { mation o }\end{array}$ & $h^{-1}$ & \multicolumn{2}{|c|}{$P=\alpha I N /\left(N+K_{n I}\right)-R$} \\
\hline
\end{tabular}

deficits $\left(0.35 \mathrm{mmol} \mathrm{P} \mathrm{m}^{-2} \mathrm{~d}^{-1}\right.$ and $5.8 \mathrm{mmol} \mathrm{N} \mathrm{m}^{-2} \mathrm{~d}^{-1}$, cf. Table 2) correspond to a descent of the nutricline by $0.7 \mathrm{~m} \mathrm{~d}^{-1}$ and $1.0 \mathrm{~m} \mathrm{~d}^{-1}$, respectively, which is twice the simulated descent rate of 0.3 to $0.5 \mathrm{~m} \mathrm{~d}^{-1}$ (Fig. 11). We did not succeed in finding a realistic set of model constants that would allow simulation of descent rates as high as those apparently observed.

Despite this quantitative discrepancy it remains evident that the phytoplankton maximum during its de-

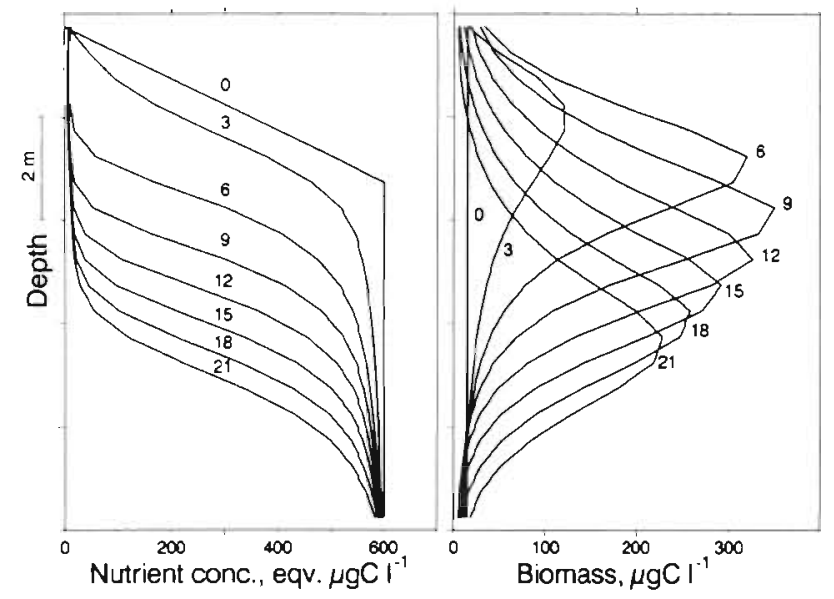

Fig. 11. Output from model with parameter settings given in Table 7. Labels for each curve specify time in days scent through the upper part of the bottom water utilized new nutrients for biomass build up and for export production. The rate of new production may be estimated by 3 independent approaches: from the increase in nutrient deficits, from isotope uptake, and from carbon balances of production and loss for the whole system (Table 6).

The highest estimates of new production (445 to 460 $\mathrm{mg} C \mathrm{~m}^{-2} \mathrm{~d}^{-1}$ ) were derived from observed increases of apparent nitrate and phosphate deficits. This approach may yield estimates that exceed the actual new production rate, either because the observed deficits were due to physical rather than biological processes, or because the 3 successive transects did not reflect real-time (i.e. the later transects represented water parcels with longer subsurface bloom history). The biological interpretation (i.e. that deficits represent consumption by plankton) is supported by the fact that increases in nitrate and phosphate deficits yield almost the same estimate of new production, i.e. the ratio between increases in nitrate and phosphate deficits is close to the Redfield ratio and far from the $\mathrm{N}$ : P ratio in the bottom water (ca $12 \mathrm{~mol}$ : mol). On the other hand, model simulations indicated that the observed increases in nutrient deficits (as expressed by the descent rate of the nutricline) were unrealistically high (cf. above). 
Table 6. Six independent estimates of new production in central Skagerrak during 8 to 14 June 1990

\begin{tabular}{|c|c|}
\hline Basis and assumptions & $\begin{array}{l}\text { New production } \\
\left(\mathrm{mg} \mathrm{C} \mathrm{m}^{2} \mathrm{~d}^{-11}\right.\end{array}$ \\
\hline Increase in nitrate deficit ${ }^{\text {i, } b}$ & 460 \\
\hline Increase in phosphate deficit ${ }^{d, c}$ & 445 \\
\hline${ }^{15} \mathrm{NO}_{3}$ uptake in subsurface layer ${ }^{\mathrm{b}}$ & 105 \\
\hline${ }^{32} \mathrm{PO}_{4}$ uptake in subsurface layer ${ }^{c, d}$ & 290 \\
\hline Vertical carbon flux ${ }^{e}+$ phytoplankton biomass increase ${ }^{d, f}$ & 255 \\
\hline Total primary production ${ }^{g}$ - bacterial gross production ${ }^{g} \cdot h$ & 100 \\
\hline \multicolumn{2}{|l|}{${ }^{\circ}$ Cf. Table 4} \\
\hline \multicolumn{2}{|l|}{${ }^{\mathrm{b}}$ Assuming molar $\mathrm{C}: \mathrm{N}=106: 16$ [Redfield 1.958) } \\
\hline \multicolumn{2}{|l|}{${ }^{\circ}$ Assuming molar $\mathrm{C}: \mathrm{P}=106: 1$ (Redfield 1958) } \\
\hline \multicolumn{2}{|l|}{${ }^{\mathrm{d}}$ Assuming new : total uptake $=0.35$ (cf. Fig. 8) } \\
\hline \multicolumn{2}{|l|}{ eff. Table 6} \\
\hline \multicolumn{2}{|l|}{${ }^{1}$ Assuming phytoplankton $\mathrm{C}$ : chlorophyll $=30$} \\
\hline \multicolumn{2}{|l|}{ Cf. Table 3} \\
\hline${ }^{h}$ Assuming a bacterial growth yield of $30 \%$ & \\
\hline
\end{tabular}

estimate of new production, however, it produced the lowest estimate of all (100 $\left.\mathrm{mg} \mathrm{C} \mathrm{m} \mathrm{m}^{-2} \mathrm{~d}^{-1}\right)$. If only the subsurface layer is considered, the apparent net primary production $(160$ mg $\mathrm{C} \mathrm{m}^{-2} \mathrm{~d}^{-1}$ ) almost balances bacterial gross production $1120 \mathrm{mg} \mathrm{C} \mathrm{m}^{-2}$ $\mathrm{d}^{-1}$ ).

This comparison suggests that primary production in the subsurface layer was underestimated by the applied procedure, which was based on establishing a $P-I$ relationship for one depth from the subsurface layer by ${ }^{14} \mathrm{C}$-incorporation measured in a lab incubator. Our procedure for calculation of primary production does not account for decreased light transmission in the subsurface chlorophyll maximum or for a possible light inhi-

Lower estimates of new production were derived from uptake rates of nitrate and phosphate in the subsurface layer, as measured by tracer experiments. In particular, ${ }^{15} \mathrm{NO}_{3}$-incorporation produced low uptake rates, corresponding to about $105 \mathrm{mg} \mathrm{C} \mathrm{m}^{-2} \mathrm{~d}^{-1}$. Some additional new production may have been fuelled by ammonia and dissolved organic nitrogen (DON), although these contributions were probably minor, given the low concentrations of ammonia observed and the presumably low degradability of DON in the bottom water. The calculation of new production from ${ }^{32} \mathrm{PO}_{4}$ uptake depends on the ratio between new and total uptake, which in this case was determined indirectly through a comparison of uptake and remineralisation rates (Fig. 8). It was assumed that new production was restricted to the subsurface layer.

New production was also estimated from carbon balances in 2 different ways. One estimate was reached by adding sedimentation loss (165 $\mathrm{mg} \mathrm{C}^{-2} \mathrm{~d}^{-1}$ ) and biomass build-up $\left(3 \mathrm{mg}\right.$ chlorophyll $\mathrm{m}^{-2} \mathrm{~d}^{-1}$ corresponding to $\left.90 \mathrm{mg} \mathrm{C} \mathrm{m}^{-2} \mathrm{~d}^{-1}\right)$. An additional contribution from heterotrophic biomass build-up amounted to less than $20 \mathrm{mg} \mathrm{C} \mathrm{m}^{-2} \mathrm{~d}^{-1}$ (Table 1). Another estimate was reached from the measured apparent net primary

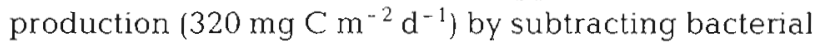
gross production, assuming that bacterioplankton are reponsible for a major part of the regeneration and that most of the bacterial net production is dissipated in the microbial food web, i.e. that bacterioplankton act as a sink for carbon (Ducklow et al. 1986). In the present case, however, it is likely that herbivorous micrograzers (viz. ciliates and heterotrophic dinoflagellates) were responsible for a substantial excretion of nutrients which had not been processed by bacteria. Consequently, this estimation should yield a maximum bition in the surface layer.

Further indications of an underestimation of subsurface phytoplankton production arise when the carbon demand of the pelagic food web is considered (Fig. 12). Given the almost equal production rates of phytoplankton and bacteria in the surface and subsurface layers, and the biomass build-up in the surface layer, less carbon apparently remains available in the subsurface layer to feed a larger zooplankton biomass.
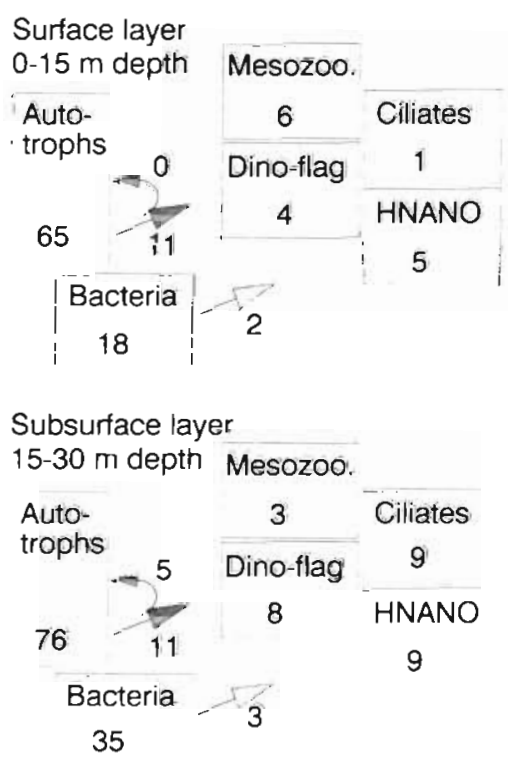

\section{"New production" Sedimentation}

Fig. 12. Draft carbon budgets for surface and subsurface layers. Pools are given in $\mu \mathrm{g} \mathrm{C} \mathrm{^{-1 }}$, fluxes in $\mu \mathrm{g} \mathrm{Cl}^{-1} \mathrm{~d}^{-1}$ See text for abbreviations 
Mesozooplankton biomass is indeed higher in the surface layer, but the carbon demand of this zooplankton

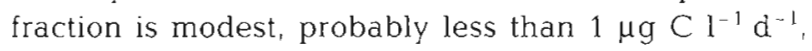
part of which may derive from the smaller zooplankton fractions.

The HNANO fraction (heterotrophic nanoflagellates other than dinoflagellates) is supposedly bacteriovor. ous, and the bacterial net production in each layer can meet the carbon demand, assuming a specific HNANO clearance of $10^{5} \mathrm{~h}^{-1}$ at $20^{\circ} \mathrm{C}$ (Fenchel 1982) and a $Q_{10}$ of 2.8 (e.g. Sherr et al. 1988). The HNANO production that can be passed on to the pelagic food web amounts to ca $1 \mu \mathrm{g} \mathrm{Cl}^{-1} \mathrm{~d}^{-1}$ in both layers, assuming a growth yield of 30 to $40 \%$ (Fenchel 1982).

Heterotrophic dinoflagellates and ciliates are supposedly herbivores. The lower temperature in the subsurface layer may explain a reduced specific activity, but given the much higher biomass of heterotrophic dinoflagellates and ciliates and the higher food density in the subsurface layer, we would expect a higher carbon demand from micrograzers in the subsurface layer. Rosenberg et al. (1990) met similar difficulties in balancing autotrophic production and heterotrophic consumption.

The subsurface phytoplankton maximum studied here represented a combination of new and regenerated production and it seemed to sustain both micrograzers and export production. The ultimate fate of this subsurface maximum remains unknown. An extrapolation of the model simulation predicts that as the phytoplankton maximum descends through the water column and becomes increasingly light limited, respiration expenses will eventually exceed photosynthesis and consequently the phytoplankton maximum will decay. The rapid growth of ciliates (Table 1) may contribute to the extinction of the phytoplankton maxjmum. On the other hand, strong wind mixing or lateral convection could bring the phytoplankton maximum closer to the surface, where it could seed a new bloom.

Acknowledgements. Danish participation in the ICES coordlnated SKAGEX Study was made possible through support from the Danish Environmental Protection Agency (HF-90) and the Danish Natural Science Research Council (J. no. 118391). We thank Jesper Andersen, Alice Christoffersen, Hanne Ferdinand, Lotte Hansen, Jack Melbye, Alexandra Claudius Nielsen and Lisbeth Olsen and the crew of RV 'Gunnar Thorson' for technical assistance. Drs Bernt Dybern, Lars Edler, Ingemar Olsson, Francisco Rey and Lembit Talpsepp kindly provided data from other SKACEX cruises.

\section{LITERATURE CITED}

Barth, H., Nielsen, A. (1989). The occurrence of Chrysochromulina polylepis in the Skagerrak and
Kattegat in May/June 1988: an analysis of extent, effects and causes. Water pollution report no. 10. Commission of the European Communities, Luxembourg

Bienfang, P., Szyper, J., Laws, E. (1983). Sinking rate and pigment responses to light-limitation of a marine diatom: implications to dynamics of chlorophyll maximum layers. Oceanol. Acta 6: 55-62

Bjørnsen, P. K., Kuparinen, J (1991). Determination of bacterioplankton biomass, net production and growth efficiency in the Southern Ocean. Mar. Ecol. Prog. Ser. 71 : $185-194$

Bjørnsen, P. K., Nielsen, T. G. (1991). Decimeter heterogeneity in the plankton during a pycnocline bloom of Gyrodinium aureolum. Mar Ecol. Prog. Ser 73: $263-267$

Carlberg, S. (1972). New Baltic manual. Comm. Meet. int. Coun. Explor. Sea C.M.-ICES/A: 29: 57-90

Cushing, D. H. (1959). On the nature of production in the sea. Fishery Invest. Lond. (Ser. 2) 22: 1-40

Danielssen, D. S., Davidson, L., Edler, L., Fogelquist, E., Fonselius, S. H., Foyn, L., Hernroth, L., Håkanssen, B., Olsson, I., Svendsen, E. (1991). SKAGEX: some preliminary results. Comm. Meet. int. Coun. Explor. Sea C.M.ICES/C: 2

Dodge, J. D. (1985). Marine dinoflagellates of the British Isles. Her Majesty's Stationary Office, London

Ducklow, H. W., Purdie, D. A., Williams, P. J. leB., Davies, J. M. (1986). Bacterioplankton: a sink for carbon in a coastal marine plankton community. Science 232: 865--867

Dugdale, R. C. Goering, J. J. (1967). Uptake of new and regenerated forms of nitrogen in primary productivity. Limnol. Oceanogr. 12: 196-206

Edler, L. (ed.) (1979). Recommendations on methods for marine biological studies in the Baltic Sea; phytoplankton and chlorophyll. Baltic Marine Biologists (BMB) Publ. No. 5. Lund, p. $1-38$

Eppley, R. W., Rogers, J N., McCarthy, J J. (1969). Halfsaturation constants for uptake of nitrate and ammonium by marine phytoplankton. Limnol. Oceanogr. 14: $912-920$

Fenchel, T., Finlay, B. J (1983). Respiration rates in heterotrophic, free-living protozoa. Microb. Ecol 9: 99-122

Fenchel, T (1982). Ecology of heterotrophic microflagellates. II. Bioenergetics and growth. Mar. Ecol. Prog. Ser. 8: $225-231$

Fuhrman, J. A., Azam, F. (1980). Bacterioplankton secondary production estimates for coastal waters off British Columbia, Antarctica and California. Appl environ. Microbiol. 39: 1085-1095

Haas, L. W. (1982). Improved epifluorescence microscopy for observing planktonic micro-organisms. Ann. Inst. Océanogr. (Paris) 58 (Suppl.): 261-266

Harris, G. P. (1978). Photosynthesis, productivity and growth: the physiological ecology of phytoplankton. Arch. Hydrobiol. 80: 405-457

Harrison, W. G., Harris, L. R. (1986). Isotope dilution and its effect on measurement of nitrogen and phosphorus uptake by oceanic microplankton. Mar. Ecol. Prog. Ser. 27. $253-261$

Hobbie, J. E., Daley, R. J., Jaspers, S. (1977). Use of Nuclepore filters for counting bacteria by epifluorescence. Appl. environ. Microbiol. 33: 1225-1228

Jespersen, A.-M., Christoffersen, K. (1987). Measurement of chlorophyll-a from phytoplankton using ethanol as extraction solvent. Arch. Hydrobiol. 109: 445-454

Kaas, H. Larsen, J., Møhlenberg, F., Richardson, K. (1992). The Chrysochromulina polylepis bloom in the Kattegat (Scandinavia) May-June 1988. Distribution, primary pro- 
duction and nutrient dynamics in the late stage of the bloom. Mar. Ecol. Prog. Ser. 79: 151-161

Kahl, A. (1932). Urtiere oder Protozoa. I. Wimpertiere oder Ciliata (Infusoria). 3. Spirotricha. In: Dahl, F (ed.) Die Tierwelt Deutschlands und der angrenzende Meeresteile. Gustav Fisher Verlag, Jena, p. 399-650

Kiørboe, T., Nielsen, T. G. (1990). Effects on wind stress on vertical water column structure, phytoplankton growth and productivity of planktonic copepods. In: Barnes, M. Gibson, R. N. (eds.). Trophic relationships in the marine environment. Aberdeen University Press, Aberdeen, $p$ $28-40$

Lee, S., Fuhrman, J. A. (1987). Relationships between biovolume and biomass of naturally derived marine plankton Appl. environ. Microbiol. 53: 1298-1303

Leegaard, C. (1915). Untersuchungen über einige planktonciliaten des Meeres. Nytt Mag. Naturvid. 53: 1-37

Legendre, L., Demers, S. (1984). Towards dynamic biological oceanography and limnology. Can. J. Fish. Aquat. Sci. 41 $2-19$

Lindahl, O., Hernroth, L. (1983). Phyto-zooplankton community in the coastal waters off Western Sweden - an ecosystem off balance. Mar. Ecol. Prog. Ser. 10: 119-126

Lynn, D. J., Montagnes, D. J. S., Small, E. B. (1988) Taxonomic description of some conspicuous species in the family Strombidiiae (Ciliophora: Oligotrichida) from the Isles of Shoals, Gulf of Maine. J. mar. biol. Ass. U.K. 68 $259-276$

Nielsen, G. E., Bresta, A.-M. (1984). Guidelines for measurement of phytoplankton primary production. Baltic Marine Biologists Publ. No. 1: 1-23, Charlottenlund

Nielsen, T G., Kiørboe, T., Bjørnsen, P. K. (1990). Effect of a Chrysochromulina polylepis subsurface bloom on the planktonic community. Mar. Ecol. Prog. Ser. 62: 21-35

Nielsen, T G., Løkkegaard, B., Richardson, K., Bo Pedersen, F., Hansen, L. (1993). Structure of plankton communities in the Dogger Bank area (North Sea) during a stratified situation. Mar. Ecol. Prog. Ser. 95: 115-131

Nielsen, T G. (1991). Contribution of zooplankton grazing to the decline of a Ceratium bloom. Limnol. Oceanogr. 36 : $1091-1106$

Olsen, V., Lundgren, B. (1984). A compact eight-channel continuous flow analyzer for shipboard use. Comm. Meet. int. Counc. Explor. Sea C.M.-ICES/C: 19

Pedersen, F. B. (1990). Hydrografiske grundelementer i de indre danske farvande. ISVA, Danish Techn. University, Lyngby

Pingree, R. D., Holligan, P. M., Mardell, G. T Harris, R. P. (1982). Vertical distribution of plankton in the Skagerrak

This article was submitted to the editor in relation to doming of the seasonal thermocline. Cont. Shelf. Res. 1: 209-219

Pond, S., Puckard G. L. (1989). Introductory dynamical oceanography:, 2nd edn. Pergamon Press, Oxford

Redfield, A C. (1958). The biological control of chemical factors in the environment. Am. Scient. 46: 205-221

Richardson, K. (ed.) (1987). Primary production: guidelines for measurement by ${ }^{14} \mathrm{C}$ incorporation. ICES Techniques in Marine Environmental Sciences No. 5, Copenhagen

Richardson, K., Christoffersen, A. (1991). Seasonal distribution and production of phytoplankton in the Southern Kattegat. Mar. Ecol. Prog. Ser. 78: 217-227

Richardson, K., Kullenberg, G. (1987). Physical and biological interactions leading to phytoplankton blooms: a review of Gyrodinium aureolum blooms in Scandinavian waters. Rapp. P-v. Réun. Cons. int. Explor. Mer 187: 19-26

Riemann, B., Bjornsen, P. K., Newell, S., Fallon, R. (1987) Calculation of cell production of coastal marine bacteria based on measured incorporation of ${ }^{3} \mathrm{H}$-thymidine. Limnol. Oceanogr. 32: 471-476

Rosenberg, R., Dahl, E., Edler, L., Fyrberg, L., Granéli, E., Granélı, W., Hagström, ̊.,Lindahl, O., Matos, M. O., Petterson, K., Sahlsten, E., Tiselius, P., Turk, V., Wikner, J. (1990). Pelagic nutrient and energy transfer during spring in the open and coastal Skagerrak. Mar. Ecol. Prog. Ser. 61. $215-231$

Rydberg, L., Edler, L., Floderus, S., Granéli, W. (1990) Interaclions between supply of nutrients, primary production, sedimentation and oxygen consumption in the SE Kattegat. Ambio 19: 134-141

Sherr, B. F., Sherr, E. B., Rassoulzadegan, F. (1988). Rates of digestion of bacteria by marine phagotrophic protozoa temperature dependence. Appl. environ. Microbiol. 54: $1091-1095$

Smetacek, V., Pollehne, F. (1986). Nutrient cycling in pelagic systems a repraisal of the conceptual framework. Ophelia 26: $401-428$

Steele, $J$ H. (1974). The structure of marine ecosystems. Harvard Univ. Press, Cambridge

Taylor, A H., Harris, J. R. W., Aiken, J. (1986). The interaction of physical and biological processes in a model of the vertical distribution of phytoplankton under stratification. In: Nihoul, J. C. J. (ed.). Marine interfaces ecohydrodynamics. Elsevier Oceanography Series 42, Amsterdam, p. $313-331$

Utermöhl, H. (1958). Zum Vervolkommung der quantitativen Phytoplankton Methodik. Mitt. Int. Ver. Limnol

Weast, R. C. (ed.) (1975). Handbook of chemistry and physics, 56 th edn CRC Press, Cleveland

Manuscript first received: September 24, 1992

Revised version accepted: March 9, 1993 